\title{
Metal-Phenolic Networks as a Versatile Platform to Engineer
}

\section{Nanomaterials and Biointerfaces}

Hirotaka Ejima, Joseph J. Richardson, Frank Caruso*

ARC Centre of Excellence in Convergent Bio-Nano Science and Technology, and the Department of Chemical and Biomolecular Engineering, The University of Melbourne, Parkville, Victoria 3010, Australia.

*Corresponding Author: Email: fcaruso@unimelb.edu.au, Tel: +61 38344 3461, Fax: +61 383444153.

\section{Present Address:}

H.E.: Institute of Industrial Science, The University of Tokyo, 4-6-1 Komaba, Meguro-ku, Tokyo 153-8505, Japan.

J.J.R.: CSIRO Manufacturing, CSIRO Private Bag 10, Clayton South, Victoria 3169, Australia. 


\section{Research Highlights}

- We review metal-phenolic networks (MPNs), a versatile class of surface coatings and nanostructured functional materials.

- Diverse substrates can be coated owing to the universal adherent properties of phenolic moieties.

- Coordinated metal ions can be used for cross-linking the films and for engineering additional functionality.

- Applications including sensing, imaging, drug delivery, live-cell protection, and catalysis are highlighted.

Keywords: Metal-phenolic networks (MPNs); Self-assembly; Polyphenols; Organicinorganic hybrid materials; Surface functionalization. 


\section{Introduction}

Coatings are useful for engineering specific and desired properties into materials. Moreover, the conformal coating of nanoscale objects is more important than ever, as nanotechnology is being adopted by disparate scientific fields. For example, thiol chemistry [1] is commonly used to engineer the surface properties of gold nanoparticles (AuNPs), thereby controlling pharmacokinetic and organ/tissue distribution during targeted drug delivery and photothermal cancer therapy [2]. Specifically, thiolated biocompatible polymers such as poly(ethylene glycol) (PEG) can be conjugated to AuNPs to reduce cytotoxicity, improve their in vivo stability, and prolong their systemic circulation lifetime [3]. For hydroxy terminated substrates, including silicon and glass, silane coupling agents (e.g., R-Si(OH) 3 ) are widely used for surface modification [4]. Phosphonic acids (e.g., $\mathrm{R}-\mathrm{PO}_{3} \mathrm{H}_{2}$ ) also readily react with a range of metal oxides to form a dense coating on the surface, and phosphonic acids are sometimes superior to silane coupling agents because of the higher robustness of metal-OP over metal-OSi bonds [5]. Phosphonic acid-mediated coating prevents oxygen diffusion toward the metal surfaces, thereby protecting the coated materials from corrosion [6]. However, these technologies are seldom applicable to a wide variety of substrates, as they require specific interactions with the substrate [7].

Facile coating techniques should be substrate-independent, and therefore applicable to a substrate regardless of its chemical composition, size, shape, or stiffness. To develop such coatings, solution-based noncovalent interactions (e.g., electrostatic interaction, hydrogen bonding, hydrophobic attraction, and van der Waals interaction) are exploited, as these interactions occur on nearly all types of surfaces. Additionally, as most individual noncovalent interactions are not strong enough to stably tether the coating to a surface, the adhesive units are generally incorporated into polymer backbones to generate multivalency [7]. For example, layer-by-layer (LbL) assembly can be utilized to fabricate polymeric thin 
films on a wide range of surfaces through the sequential adsorption of polyanions and polycations [8, 9]. Unlike spin coating and chemical vapor deposition, LbL assembly can be used to coat both planar and particulate substrates. This topology-independent conformal nature allows for the deposition of homogeneous coatings on colloidal materials of different composition (e.g., polymer, inorganic, liquid droplets, gas bubbles) and geometry (e.g., spheres, rods, fibers) [10]. Despite the significant progress being made, the requisite multistep layering process of LbL assembly is often labor intensive and time consuming. To reduce the manual involvement and speed up the assembly time, a number of studies have focused on accelerating deposition kinetics and automating labor-intensive steps with robotic immersion machines [9].

Instead of utilizing multiple steps, the self-polymerization of dopamine is a one-step method to produce an adherent coating on a wide variety of surfaces [11]. Dopamine is oxidized into 5,6-dihydroxyindole in alkaline solutions and further polymerized to form three dimensionally cross-linked networks, although a substantial amount of unpolymerized dopamine and 5,6-dihydroxyindole also remain inside the network [12]. Dopamine has catechol and amine groups that are analogous to adhesive proteins secreted by marine mussels, such as Mytilus edulis, which secretes highly basic adhesive proteins containing large amounts of lysine and 3,4-dihydroxyphenylalanine residues [13]. Amines contribute to the electrostatic interaction of the proteins and also help remove the hydrated salt layer on surfaces to allow for catechol binding [14]. Catechols can mediate either coordination interactions or bidentate hydrogen bonding to metal oxide surfaces [15]. Although, the deposition of polydopamine coatings is a one-step process, the rate of film deposition decreases as the precursor dopamine concentration increases, and it can take $10 \mathrm{~h}$ to reach a thickness of $20 \mathrm{~nm}$ [16]. 
Recently, we reported a rapid and low cost method for the conformal coating of different substrates, including bulk materials, nanomaterials, and biointerfaces [17]. In this method, the naturally occurring polyphenol, tannic acid (TA), and metal ions (e.g., Fe ${ }^{\mathrm{III}}$ ions) are simply mixed in one-pot in the presence of the substrates. Film deposition occurs due to the adsorption of the polyphenols and simultaneous cross-linking of TA by $\mathrm{Fe}^{\mathrm{III}}$. Adjacent hydroxy groups of TA provide chelating sites for $\mathrm{Fe}^{\mathrm{III}}$ ions, and the large number of gallol groups on TA facilitate efficient coordination-driven cross-linking, thereby resulting in three dimensionally stabilized metal-phenolic networks (MPNs). Moreover, film deposition is completed within several minutes, and $\mathrm{TA}$ and $\mathrm{Fe}^{\mathrm{III}}$ are readily available and inexpensive.

Since they were first reported in 2013, MPN coatings have become convenient functional nanocoatings on a diverse array of substrates (Fig. 1 and Table 1). The choices of phenolic ligands and metal ions used for film assembly have expanded, allowing for the facile generation of diverse films for a variety of applications. In this review, we summarize recent research progress in the assembly of MPNs on nanomaterials and biointerfaces. First, the assembly process and mechanisms of MPN formation are described. We then introduce specific examples of MPN-coatings on nanomaterials and biointerfaces. We conclude with future outlook and perspectives on MPN coatings. 

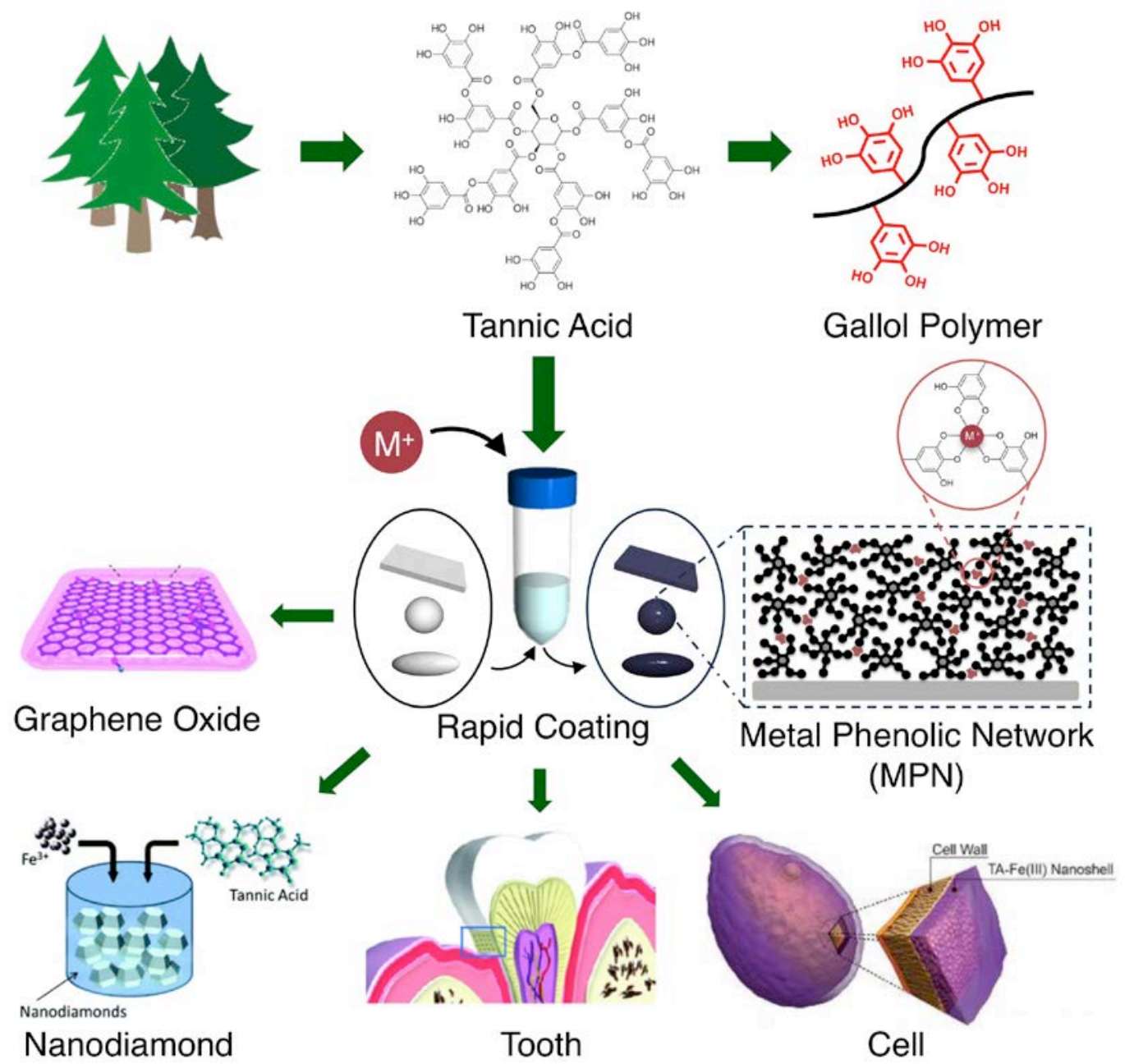

Fig. 1 Overview of metal-phenolic networks (MPNs) as a versatile coating platform to engineer nanomaterials and biointerfaces. Tannic acid (TA) is the phenolic ligand in this figure. Modified from ref. [17-21] with permission of American Association for the Advancement of Science, PCCP Owner Societies, The Royal Society of Chemistry, Nature Publishing Group and John Wiley and Sons. 
Table 1 Summary of recent studies of MPN coatings on nanomaterials and biointerfaces.

\begin{tabular}{|c|c|c|c|c|}
\hline $\begin{array}{l}\text { Phenolic } \\
\text { ligands }\end{array}$ & $\begin{array}{l}\text { Metal } \\
\text { ions }\end{array}$ & $\begin{array}{l}\text { Coated } \\
\text { objects }\end{array}$ & Applications & Ref. \\
\hline TA & $\mathrm{Fe}^{\mathrm{III}}$ & $\begin{array}{l}\text { PS, PLGA, MF, PDMS, } \\
\mathrm{SiO}_{2}, \mathrm{Au}, \mathrm{CaCO}_{3} \\
\text { E. coli, S. epidermidis }\end{array}$ & Coating & [17] \\
\hline TA & $\mathrm{Fe}^{\mathrm{III}}$ & PS particle & $\begin{array}{l}\text { pH-responsive } \\
\text { capsules }\end{array}$ & {$[17,22]$} \\
\hline TA & $\begin{array}{l}\mathrm{Gd}^{\mathrm{III}} / \mathrm{Fe}^{\mathrm{III}} \\
\mathrm{Cr}^{\mathrm{III}} / \mathrm{Fe}^{\mathrm{III}}\end{array}$ & PS particle & Hybrid capsules & [17] \\
\hline EGCG & $\mathrm{Fe}^{\mathrm{III}}$ & PS particle & Coating & [17] \\
\hline TA & $\mathrm{Fe}^{\mathrm{III}}$ & Graphene oxide & Nano-wrapping & [18] \\
\hline $\mathrm{TA}$ & $\mathrm{Fe}^{\mathrm{III}}$ & Graphene oxide & $\begin{array}{l}\text { Mechanical } \\
\text { enhancement }\end{array}$ & [23] \\
\hline TA & $\mathrm{Fe}^{\mathrm{III}}$ & Nanodiamond & Photoluminescence & [19] \\
\hline $\begin{array}{l}\text { TA, GA, } \\
\text { EGCG }\end{array}$ & $\mathrm{Fe}^{\mathrm{III}}$ & AuNP & Catalysis & [24] \\
\hline TA & $\begin{array}{l}\mathrm{Fe}^{\mathrm{III}}, \mathrm{Mn}^{\mathrm{III}}, \\
\mathrm{Gd}^{\mathrm{III}}\end{array}$ & PS particle & MRI imaging & [25] \\
\hline TA & ${ }^{64} \mathrm{Cu}^{\mathrm{II}}$ & PS particle & PET imaging & [25] \\
\hline TA & $\mathrm{Eu}^{\mathrm{III}}, \mathrm{Tb}^{\mathrm{III}}$ & PS particle & Fluorescent capsules & [25] \\
\hline TA & $\mathrm{Rh}^{\mathrm{III}}$ & PS particle & Catalysis & [25] \\
\hline TA & $\begin{array}{c}\mathrm{V}^{\mathrm{III}}, \mathrm{Cr}^{\mathrm{III}}, \mathrm{Co}^{\mathrm{II}}, \\
\mathrm{Ni}^{\mathrm{II}}, \mathrm{Cu}^{\mathrm{II}}, \mathrm{Zn}^{\mathrm{II}}, \\
\mathrm{Zr}^{\mathrm{IV}}, \mathrm{Mo}^{\mathrm{II}}, \\
\mathrm{Ru}^{\mathrm{III}}, \mathrm{Rh}^{\mathrm{III}} \\
\mathrm{Cd}^{\mathrm{II}}, \mathrm{Ce}^{\mathrm{III}}\end{array}$ & PS particle & Hollow capsules & [25] \\
\hline TA & $\mathrm{Fe}^{\mathrm{III}}, \mathrm{Ti}^{\mathrm{IV}}$ & $\mathrm{CaCO}_{3}$ particle & $\begin{array}{l}\text { Enzyme-immobilized } \\
\text { capsules }\end{array}$ & [26] \\
\hline TA & $\mathrm{Fe}^{\mathrm{III}}$ & $\mathrm{CaCO}_{3}$ particle & $\begin{array}{l}\text { Magnetic and } \\
\text { enzyme-loaded } \\
\text { capsules }\end{array}$ & [27] \\
\hline GA, PG, PC & $\mathrm{Fe}^{\mathrm{III}}$ & PS particle & Hollow capsules & [28] \\
\hline TA & $\mathrm{Al}^{\mathrm{III}}$ & $\mathrm{CaCO}_{3}$ particle & Drug delivery & [29] \\
\hline TA & $\mathrm{Fe}^{\mathrm{III}}$ & Emulsion & $\begin{array}{l}\text { Chlorpyrifos-loaded } \\
\text { microcapsules }\end{array}$ & [30] \\
\hline Lignin & $\mathrm{Fe}^{\mathrm{III}}$ & Emulsion & Nanocapsule & [31] \\
\hline TA & $\mathrm{Fe}^{\mathrm{III}}, \mathrm{Al}^{\mathrm{III}}, \mathrm{Eu}^{\mathrm{III}}$ & $\begin{array}{l}\text { Zein/quaternized } \\
\text { chitosan } \\
\text { particle }\end{array}$ & $\begin{array}{l}\text { Drug delivery } \\
\text { Cell imaging }\end{array}$ & [32] \\
\hline $\begin{array}{c}\text { Catechol- } \\
\text { functionalized } \\
\text { PEG }\end{array}$ & $\mathrm{Fe}^{\mathrm{III}}$ & $\mathrm{CaCO}_{3}$ particle & $\begin{array}{l}\text { Low-fouling and } \mathrm{pH}- \\
\text { degradable capsules }\end{array}$ & [33] \\
\hline $\begin{array}{l}\text { Catechol- } \\
\text { functionalized } \\
\text { HA and PEG }\end{array}$ & $\mathrm{Fe}^{\mathrm{III}}$ & $\mathrm{CaCO}_{3}$ particle & Cancer cell targeting & [34] \\
\hline $\begin{array}{c}\text { Catechol- } \\
\text { functionalized } \\
\text { HA }\end{array}$ & $\mathrm{Fe}^{\mathrm{III}}$ & $\mathrm{CaCO}_{3}$ particle & $\begin{array}{c}\text { Protein corona- } \\
\text { coated MPN capsules }\end{array}$ & [35] \\
\hline
\end{tabular}




\begin{tabular}{|c|c|c|c|c|}
\hline TA & $\mathrm{Fe}^{\mathrm{III}}$ & MCM-41 & $\begin{array}{l}\mathrm{pH}-\text { and glutathione- } \\
\text { responsive release of } \\
\text { curcumin }\end{array}$ & [36] \\
\hline TA & $\mathrm{Fe}^{\mathrm{III}}$ & Paclitaxel nanocore & Anticancer therapy & [37] \\
\hline TA & $\mathrm{Fe}^{\mathrm{III}}$ & S. cerevisiae & $\begin{array}{l}\text { Cytoprotective } \\
\text { coating }\end{array}$ & [21] \\
\hline TA & $\mathrm{Fe}^{\mathrm{III}}$ & $\begin{array}{c}\text { HeLa, NIH 3T3 } \\
\text { fibroblast, Jurkat cells }\end{array}$ & $\begin{array}{l}\text { Cytoprotective } \\
\text { coating }\end{array}$ & [38] \\
\hline TA & $\mathrm{Fe}^{\mathrm{III}}$ & $\begin{array}{l}\text { S. cerevisiae, E. coli., } \\
\text { PC12 cells }\end{array}$ & $\begin{array}{l}\text { Cellular surface } \\
\text { engineering }\end{array}$ & [39] \\
\hline TA & $\mathrm{Fe}^{\mathrm{III}}$ & Brome mosaic virus & $\begin{array}{l}\text { Enhanced stability } \\
\text { Transport barrier }\end{array}$ & [40] \\
\hline TA & $\mathrm{Fe}^{\mathrm{III}}$ & Dentinal tubules & $\begin{array}{c}\text { Dental } \\
\text { hypersensitivity }\end{array}$ & [20] \\
\hline GA & $\mathrm{Fe}^{\mathrm{III}}$ & Dentinal tubules & $\begin{array}{l}\text { Dental } \\
\text { hypersensitivity }\end{array}$ & [41] \\
\hline TA & $\mathrm{Ti}^{\mathrm{IV}}$ & Chitin microsphere & $\begin{array}{l}\text { Enzyme } \\
\text { immobilization }\end{array}$ & [42] \\
\hline Dopamine & $\mathrm{Ti}^{\mathrm{IV}}$ & No substrate used & $\begin{array}{c}\text { Enzyme } \\
\text { immobilization }\end{array}$ & [43] \\
\hline TA & $\mathrm{Fe}^{\mathrm{III}}$ & $\mathrm{Fe}_{3} \mathrm{O}_{4} @ \mathrm{SiO}_{2}$ & $\begin{array}{l}\text { Protein enrichment } \\
\text { for MALDI-TOF MS }\end{array}$ & [44] \\
\hline TA & $\mathrm{Fe}^{\mathrm{III}}$ & $\begin{array}{l}\text { Polydopamine-coated } \\
\text { glass }\end{array}$ & $\begin{array}{c}\text { Adhesion of marine } \\
\text { Diatoms }\end{array}$ & [45] \\
\hline TA & $\mathrm{Fe}^{\mathrm{III}}$ & $\begin{array}{l}\text { Polydopamine-coated } \\
\text { surfaces }\end{array}$ & $\begin{array}{l}\text { Marine antifouling } \\
\text { coating }\end{array}$ & [46] \\
\hline TA & $\mathrm{Fe}^{\mathrm{III}}$ & $\begin{array}{c}\text { Zwitterionic } \\
\text { poly(MPDSAH) surface }\end{array}$ & $\begin{array}{l}\text { Micropatterned } \\
\text { adhesion of proteins } \\
\text { and cells }\end{array}$ & [47] \\
\hline $\begin{array}{l}\text { Vegetable } \\
\text { tannins }\end{array}$ & $\mathrm{Fe}^{\mathrm{III}}$ & No substrate used & $\begin{array}{l}\text { Dye sensitized solar } \\
\text { cells }\end{array}$ & [48] \\
\hline TA & $\mathrm{Fe}^{\mathrm{III}}$ & MOFs & $\begin{array}{l}\text { Etching and surface } \\
\text { functionalization }\end{array}$ & [49] \\
\hline TA & $\mathrm{Fe}^{\mathrm{III}}$ & $\begin{array}{c}\text { Polyamide } \\
\text { RO membrane }\end{array}$ & Surface modification & {$[50]$} \\
\hline TA & $\mathrm{Fe}^{\mathrm{III}}$ & $\begin{array}{c}\text { Polyamide } \\
\text { RO membrane }\end{array}$ & Anti-biofouling & [51] \\
\hline TA & $\mathrm{Fe}^{\mathrm{III}}$ & $\begin{array}{l}\text { Poly(ether suofone) } \\
\text { membrane }\end{array}$ & $\begin{array}{l}\text { Heavy metal ion } \\
\text { removal }\end{array}$ & [52] \\
\hline TA & $\mathrm{Fe}^{\mathrm{III}}$ & Cellulose fibers & $\begin{array}{l}\text { Oxygen reduction } \\
\text { catalysts }\end{array}$ & [53] \\
\hline TA & $\mathrm{Fe}^{\mathrm{III}}$ & Melamine sponge & Absorbent & [54] \\
\hline $\begin{array}{c}\text { TA, } \\
\text { polydopamine }\end{array}$ & $\begin{array}{l}\mathrm{Fe}^{\mathrm{III}}, \mathrm{Al}^{\mathrm{III}}, \mathrm{Zr}^{\mathrm{IV}}, \\
\mathrm{Ce}^{\mathrm{III}}, \mathrm{Zn}^{\mathrm{II}}\end{array}$ & $\begin{array}{c}\text { Numerous substrates, } \\
\text { see the footnote* }\end{array}$ & $\begin{array}{l}\text { Superstructuring of } \\
\text { the coated objects }\end{array}$ & [55] \\
\hline
\end{tabular}

Abbreviations in the table are: polystyrene (PS); poly(lactic-co-glycolic acid) (PLGA); melamine formaldehyde (MF); polydimethylsiloxane (PDMS); epigallocatechin gallate (EGCG); magnetic resonance imaging (MRI); positron emission tomography (PET); gallic acid (GA); pyrogallol (PG); pyrocatechol (PC); polyethylene glycol (PEG); hyaluronic acid (HA); Mobil crystalline material 41 (MCM-41); matrix-assisted laser desorption/ionization 
time-of-flight mass spectrometry (MALDI-TOF MS); 3-(methacryloylamino)propyldimethyl(3-sulfopropyl)ammonium hydroxide (MPDSAH); reverse osmosis (RO).

*Substrates include spherical particles (PS, amino-functionalized $\mathrm{SiO}_{2}$, magnetic $\mathrm{SiO}_{2}$, mesoporous $\mathrm{SiO}_{2}$, MF, $\left.\mathrm{NaYF}_{4}: \mathrm{Yb} / \mathrm{Er}, \mathrm{Ag}\right)$, nanowires ( $\left.\mathrm{ZnO}, \mathrm{AgCN}\right)$, nanorods $\left(\mathrm{SiO}_{2}, \beta\right.$ $\mathrm{FeOOH}), \mathrm{Ni}\left[\mathrm{Ni}(\mathrm{CN})_{4}\right]$ polygons, Prussian blue cubic, human microvascular endothelial cell line-1. 


\section{What are MPNs?}

MPNs are supramolecular network structures consisting of metal ions coordinated to phenolic ligands. These are ideal candidates for accessing new functionalities in stimuliresponsive coatings, because they combine specific functions imparted by the metal ions with the high affinity to a wide range of surfaces of phenolics. Crystalline porous coordination polymers (PCPs) or metal-organic frameworks (MOFs) composed of phenolic ligands with metal ions $[56,57]$ also fall into the MPN category, but these are not covered in this review. This review primarily focuses on the interfacial formation of amorphous network structures consisting of phenolic compounds with metal ions.

As a phenolic ligand, TA is of particular interest because it is already approved by the US Food and Drug Administration (FDA), although other phenolic ligands have also recently been used to construct MPNs (Table 1). TA is a dendritic polyphenol that contains five digalloyl ester groups covalently attached to a central glucose core (Fig. 1). TA exhibits antioxidant [58], antibacterial [59], antimutagenic [60] and anticarcinogenic [61] properties. Moreover, TA can chelate metals, where it acts as a polydentate ligand for metal ion coordination. As TA is just one of many naturally occurring polyphenols, this coating technique can provide a novel green route to fabricating advanced functional materials [62].

Polyphenols are secondary metabolites of plants and play essential, diverse roles in plant physiology, such as defending against UV radiation, plant-pathogens, micro-organisms and insects [63]. For the last several decades, there has been increased interest in the potential health benefits of antioxidants, where the regular intake of fruits and vegetables containing polyphenols is thought to reduce the risk of chronic and degenerative diseases, although this is still under scientific scrutiny [63]. Moreover, polyphenols have attracted significant attention from material scientists [64-74], partly because of the worldwide social and 
environmental demand for replacing petroleum-derived materials with renewable plant-based ones. 


\section{Assembly routes of MPNs: one-step vs. multistep}

MPNs consisting of $\mathrm{TA}$ and $\mathrm{Fe}^{\mathrm{III}}$ can be assembled in "one-step” [17, 25] or “multistep” [22, 75-77] routes through coordination interactions. Simply mixing the Fe ${ }^{\mathrm{III}}$ and TA simultaneously in one-pot (Fig. 2a, one-step), or instead alternately immersing the substrate in separate TA and Fe ${ }^{\mathrm{III}}$ solutions (Fig. 2b, multistep) both result in MPN formation on the substrate surface. Substantial differences are observed when comparing MPNs prepared through one-step or multistep assembly, both in the nature of complexation and in the physicochemical properties of the MPNs, such as permeability and stiffness (Fig. 2c). These results provide some insight into the assembly mechanisms and demonstrate how prudent choice of the assembly method, even when using identical material components (i.e., TA and $\mathrm{Fe}^{\mathrm{III}}$ ), can be used to tune application-specific properties.

In the case of one-step assembly (Fig. 2a), the color of the suspension immediately turns blue upon addition of TA and $\mathrm{Fe}^{\mathrm{III}}$. Since $\mathrm{TA}$ and $\mathrm{Fe}^{\mathrm{III}}$ are rapidly mixed in one-pot in the presence of substrates, small TA-Fe ${ }^{\mathrm{III}}$ complexes form in the solution and subsequently bind to the surface of the substrate in addition to the adsorption of free TA on the substrate. Monolayers with a thickness of $\sim 2 \mathrm{~nm}$ form on surfaces when solely using TA, but the onestep coating of MPNs results in a film with a thickness of $\sim 10 \mathrm{~nm}[17,76]$. After coating with TA, the zeta potential of the surface becomes negative, independent of the surface charge of the bare substrate [17]. FT-IR [25] and Raman spectra [21] can be used to confirm the formation of $\mathrm{Fe}^{\mathrm{III}} / \mathrm{TA}$ coating, while X-ray photoelectron spectroscopy (XPS) shows the Fe $2 \mathrm{p}_{3 / 2}$ signal at $713 \mathrm{eV}$ with a $2 \mathrm{p}$ peak split of $13 \mathrm{eV}$, consistent with the presence of $\mathrm{Fe}^{\mathrm{III}}$ species in the MPN films. In the $\mathrm{O}_{1 \mathrm{~s}}$ region of the XPS spectra, the HO-C group of TA shifts from $529 \mathrm{eV}$ to a higher binding energy of $532 \mathrm{eV}$ after chelation of $\mathrm{Fe}^{\mathrm{III}}$, suggesting electron transfer from TA to $\mathrm{Fe}^{\mathrm{III}}$. By varying the feed concentrations of $\mathrm{TA}$ and $\mathrm{Fe}^{\mathrm{III}}$, the resulting stoichiometries in the films can be changed between TA:Fe ${ }^{\mathrm{II}}=4: 1-2: 1$ [17]. 
Multistep assembly (Fig. 2b), where substrates are sequentially incubated in separate solutions of excess TA or Fe ${ }^{\mathrm{III}}$, leads to unique MPN film properties [22]. The unadsorbed TA or Fe $\mathrm{F}^{\mathrm{III}}$ is removed in between the incubation steps with multiple washing steps. Hence, the formation of small TA-Fe $\mathrm{F}^{\mathrm{III}}$ aggregates in solution is avoided in multistep assembly. Thus, the precise and dense layering of a TA monolayer (thickness $\sim 2 \mathrm{~nm}$ ) per cycle is possible. The multistep build-up of MPNs can be monitored via UV-visible spectrophotometry and QCM. The growth rates of multistep assembly are $\mathrm{pH}$-dependent, with the amount of deposited material increasing with increasing $\mathrm{pH}$, due to the larger association constants between $\mathrm{TA}$ and $\mathrm{Fe}^{\mathrm{III}}$ at higher $\mathrm{pH}$.

The assembly route also substantially affects the coordination mode of the obtained MPNs. Specifically, the chelation sites of TA (gallol groups) are mostly occupied with Fe $\mathrm{F}^{\mathrm{III}}$ during multistep assembly, because the amount of TA on the substrate surface is much smaller than the amount of $\mathrm{Fe}^{\mathrm{III}}$ in the bulk solution, leading to the saturation of $\mathrm{Fe}^{\mathrm{III}}$ at the chelation sites in TA. However for one-step assembly, TA and $\mathrm{Fe}^{\mathrm{III}}$ are mixed simultaneously, forming small complexes in solution that then adsorb to the surface, and therefore most of the chelation sites of TA remain unoccupied. Although the MPNs prepared through multistep assembly contain a higher $\mathrm{Fe}^{\mathrm{III}}$ content (50 mol\%) than those prepared through one-step assembly (25 mol\%), multistep assembled MPNs have a lower Young's modulus [22]. This is due to the lower percentage of cross-linked TA molecules, as not all of the Fe ${ }^{\mathrm{III}}$ contributes towards stabilizing the MPNs in the multistep assemblies. The content of $\mathrm{Fe}^{\mathrm{III}}$ contributing to the cross-linking was estimated to be 10 mol\% for multistep assembly [22] and $\sim 50 \mathrm{~mol} \%$ for one-step assembly $[17,76]$, as determined by deconvoluted $\mathrm{Fe}-\mathrm{O}$ ( $\sim 531.2 \mathrm{eV})$ and $\mathrm{Fe}-\mathrm{OH}(\sim 533.0 \mathrm{eV})$ peaks, which can be attributed to the coordination of $\mathrm{TA} / \mathrm{Fe}^{\mathrm{III}}$ and to $\mathrm{Fe}^{\mathrm{III}}$ aqua hydroxo complexes. 
(a)

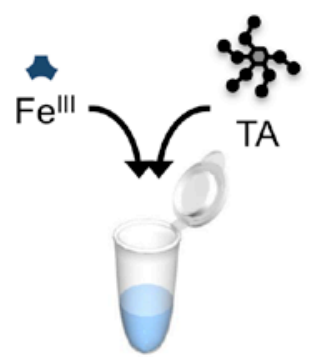

One-pot Mixing
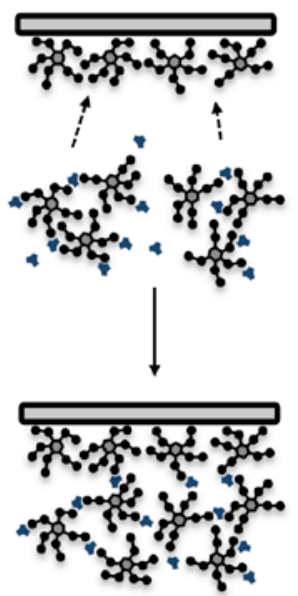

(b)

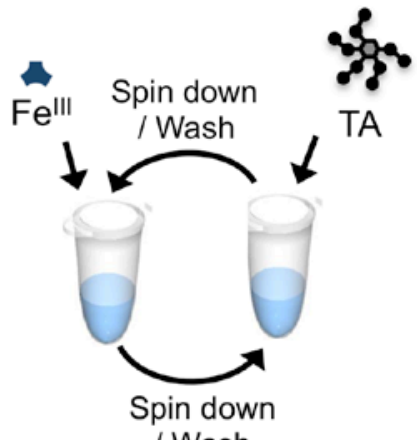

/ Wash

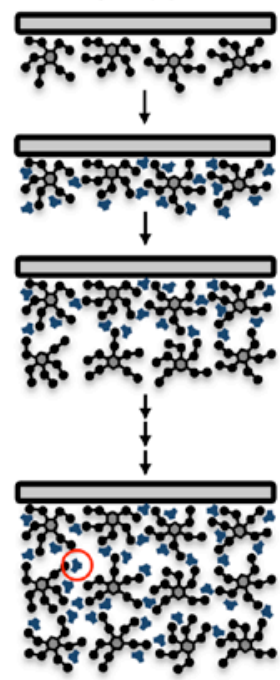

(c)

$\begin{array}{ccl}\text { Time required } & \text { Seconds } & \text { Hours } \\ \text { Thickness/cycle } & 10 \mathrm{~nm} & 2 \mathrm{~nm} \\ \text { Modulus } & 1.0 \mathrm{GPa} & 0.4 \mathrm{GPa} \\ \text { Molecular Weight } & \sim 100 \mathrm{kDa} & \sim 10 \mathrm{kDa} \\ \text { Cut-Off } & & \end{array}$

Fig. 2 One-step (a) and multistep (b) assembly of MPNs. Time required for a $\sim 10 \mathrm{~nm}$ coating, the thickness per one cycle, and the physicochemical properties of MPNs (permeability and stiffness) are summarized in (c). 


\section{Functional MPN coatings for template-mediated capsule fabrication}

Both planar and particulate objects can be coated with MPNs (Table 1), and hollow MPN capsules can be readily obtained by coating sacrificial template particles, followed by selective dissolution of the templates [17, 78]. Due to the conformal nature of MPNs, different-sized spherical templates $(D=120 \mathrm{~nm}-10 \mu \mathrm{m})$ and ellipsoidal templates can be exploited to form MPN capsules with nominally the same size and shape as the templates [17]. MPN coatings are relatively thin, and after drying, the capsules collapse and display folds and creases on their surfaces, as observed by atomic force microscopy (AFM), scanning electron microscopy (SEM) and transmission electron microscopy (TEM) (Fig. 3).

(a)

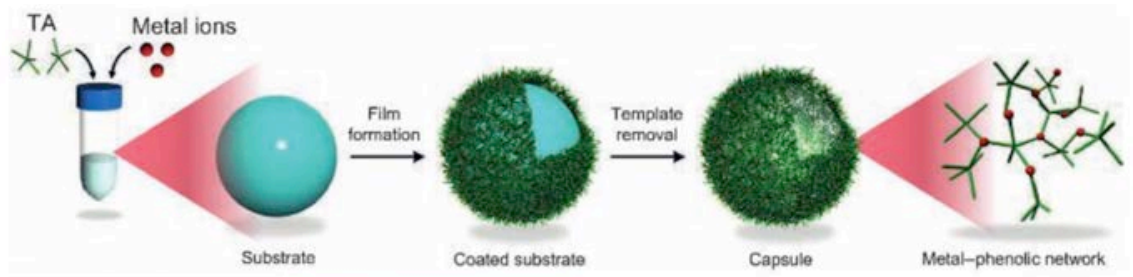

(b)

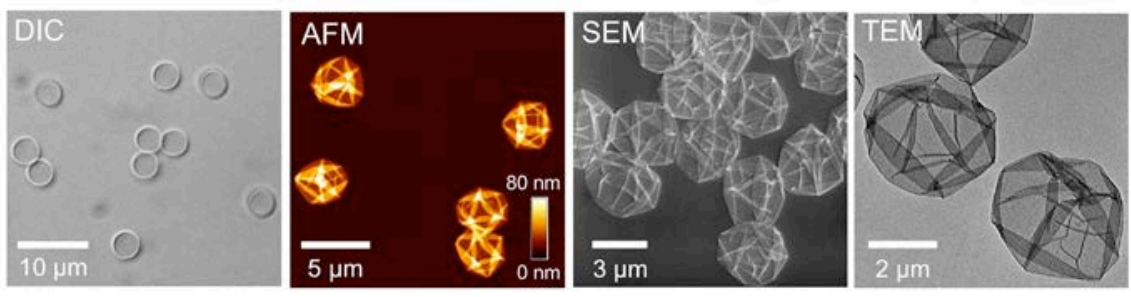

Fig. 3 Template-mediated MPN capsule fabrication. (a) Assembly of TA and metal ions to form a MPN film on a sacrificial particle template, followed by template removal. (b) Differential interference contrast (DIC) microscopy, atomic force microscopy (AFM), scanning electron microscopy (SEM) and transmission electron microscopy (TEM) images of MPN capsules. Adapted from ref. [17, 25] with permission from American Association for the Advancement of Science and John Wiley and Sons.

TA can coordinate with a variety of metals, leading to a broad library of functional MPN capsules [25]. The disassembly kinetics of MPN capsules is dependent on the metal species used, as each metal has a different affinity towards TA. At pH 5 for example, over 
$25 \%$ of $\mathrm{Cu}^{\mathrm{II}}$-TA capsules disassemble within $1 \mathrm{~h}$, whereas it takes roughly $6 \mathrm{~h}$ for $25 \%$ of $\mathrm{Al}^{\mathrm{III}}$-TA capsules to disassemble, and even after $168 \mathrm{~h}$, less than 25\% of $\mathrm{Zr}^{\mathrm{IV}}$-TA capsules disassemble. The intermediate disassembly kinetics of the $\mathrm{Al}^{\mathrm{III}}$-TA capsules correspond to a desirable profile for drug delivery [29], as the capsules are relatively stable at the $\mathrm{pH}$ of the bloodstream ( $\mathrm{pH}$ 7.4), but gradually disassemble at lower $\mathrm{pH}$ values that correspond to what is experienced in endosomal and lysosomal compartments during cellular uptake and trafficking (pH 5-6). Fragmentation of the $\mathrm{Al}^{\mathrm{III}}$-TA capsules due to degradation in JAWS II cells was verified by deconvolution fluorescence microscopy (Fig. 4a).

Other than disassembly kinetics, metals can also be used to impart other unique functionalities to the MPN capsules. For example, radioactive ${ }^{64} \mathrm{Cu}^{\mathrm{II}}$-TA capsules are useful for tracking the biodistribution of the MPN carrier, because ${ }^{64} \mathrm{Cu}^{\mathrm{II}}$ is a probe for positron emission tomography (PET) imaging (Fig. 4b). PET images showed major uptake of the capsules in the liver and minor uptake in the spleen, as a consequence of the reticuloendothelial system that processes microparticles in the bloodstream. Further investigations on the effect of size, shape and surface chemistry on the biodistribution is needed to determine the optimum physicochemical properties for prolonged MPN capsule circulation. Other metals incorporated into MPN capsules, including $\mathrm{Fe}^{\mathrm{III}}$-, $\mathrm{Mn}^{\mathrm{II}}$-, and $\mathrm{Gd}^{\mathrm{III}}$ TA capsules, function as magnetic resonance imaging (MRI) contrast agents (Fig. 4d). Among these three capsules, $\mathrm{Mn}^{\mathrm{II}}$-TA capsules displayed the highest relaxivity $r_{2}$, which is of the order of $60 \mathrm{~s}^{-1} \mathrm{mM}^{-1}$ and generally sufficient for in vivo use. Dual metal capsules can be prepared for improved functionality in terms of biomedical imaging. For example, highly distributed signals from $\mathrm{Cu}^{\mathrm{II}}$ and $\mathrm{Eu}^{\mathrm{III}}$ were detected by energy dispersive $\mathrm{X}$-ray spectroscopy (EDX) mapping analysis (Fig. 4c), where the dual metal capsules have a multimodal capability for both PET and fluorescence imaging. 
(a)

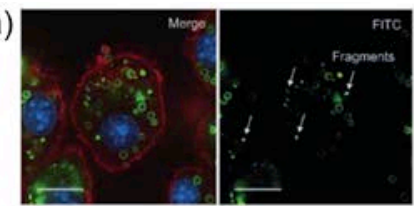

(c)

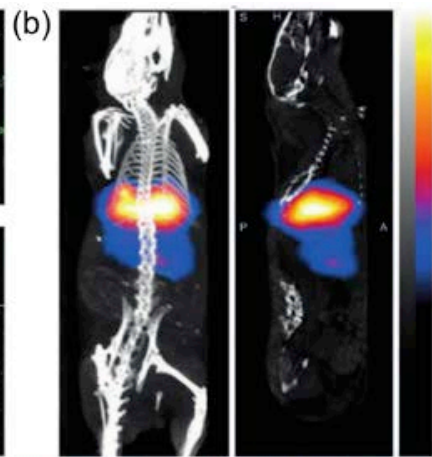

(d)
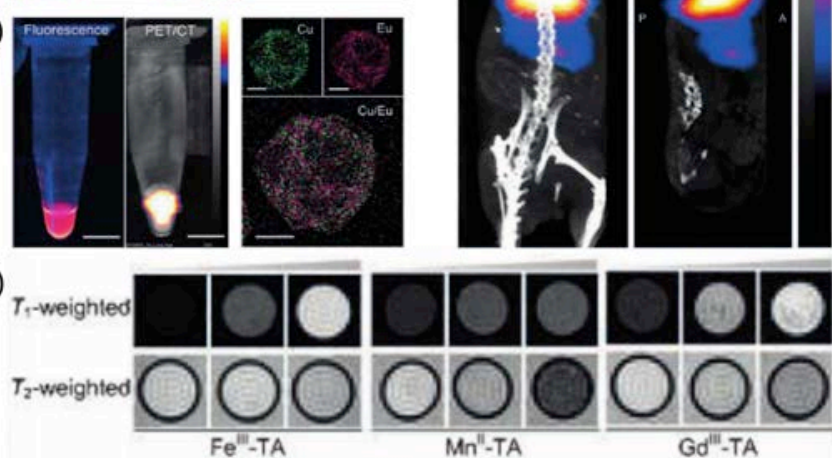

Fig. 4 Multifunctional MPN capsules. (a) Uptake and disassembly of $\mathrm{Al}^{\mathrm{III}}-\mathrm{TA}$ capsules in JAWS II cells, as imaged by deconvolution fluorescence microscopy. (b) PET images of BALB/c mice injected with $1 \mathrm{MBq}{ }^{64} \mathrm{Cu}^{\mathrm{II}}$-TA capsules via a lateral tail vein. (c) Fluorescence and PET pseudo-color images, and EDX elemental mapping of dual metal MPN capsules. (d) MRI phantom images of capsules immobilized in agarose. $T_{1}$-weighted inversion recovery images and $T_{2}$-weighted spin echo images of samples with three different metal concentrations are shown. Adapted from ref. [25] with permission from John Wiley and Sons.

Metalloid (boron) containing molecules can be used instead of metal ions for MPN capsule formation. For example, Guo et al., constructed $\mathrm{pH}$ and cis-diol dual-responsive capsules from phenylboronic acid and TA [79]. The release of anticancer drugs from the capsules could be controlled by decreasing the $\mathrm{pH}$ and/or by adding cis-diols. The capsules were stable in human blood plasma for $12 \mathrm{~h}$, even in the presence of competing carbohydrates, but were capable of disassembling in the presence of $100 \mathrm{mM}$ mannitol (Fig. 5a). The phenylboronic acid-based MPN capsules were injected locally to the site of tumor xenografts in immunodeficient mice and tracked via PET imaging (Fig. 5b). If the capsules disassembled in vivo, the PET signal should have been detected from the liver; however, the PET signal was still primarily detected from the tumor site after $12 \mathrm{~h}$, suggesting that these 
capsules exhibited good stability in vivo. This efficient combination of TA with boron-based cross-linkers could possibly lead to a closed-loop insulin delivery system activated by glucose.
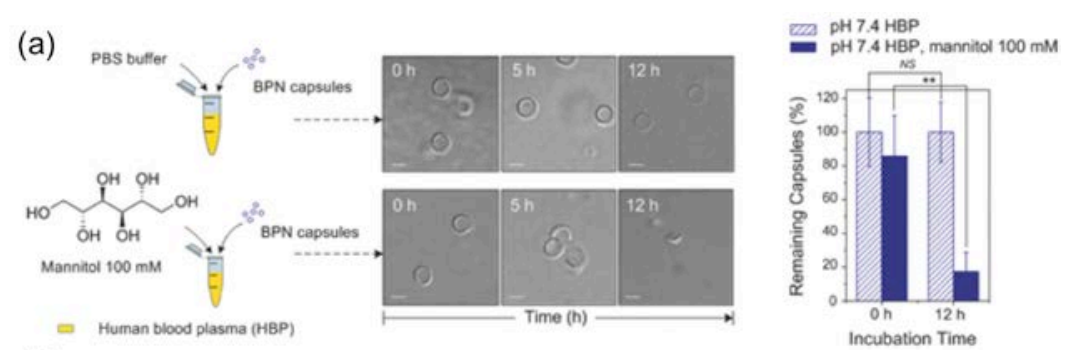

(b)

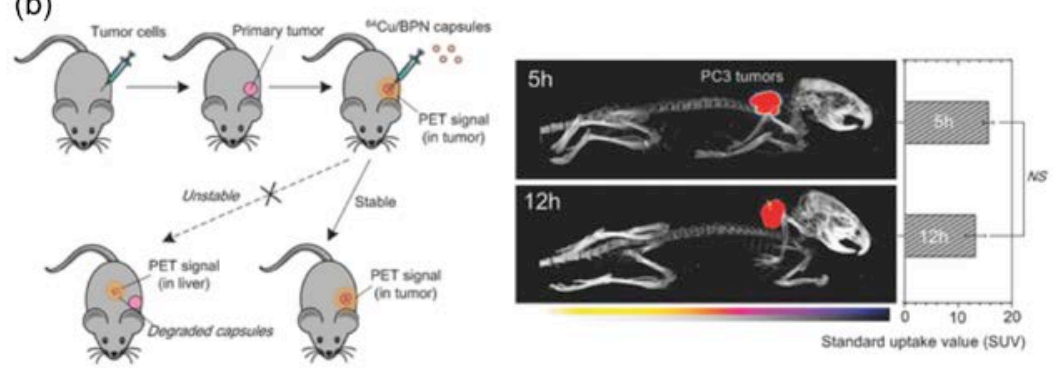

Fig. 5 Stability of dual-responsive phenylboronic acid-TA capsules. (a) Capsules incubated in human blood plasma solution with or without $100 \mathrm{mM}$ mannitol at different times. (b) Capsules injected to the site of tumor xenografts in immunodeficient mice. Adapted from ref. [79] with permission from John Wiley and Sons.

Synthetic polyphenols can also be generated through the modification of polydentate polymers (e.g., multi-arm PEG) with catechol groups, which can then be used to form multifunctional MPN capsules. For example, catechol-functionalized PEG-based MPN capsules show reduced nonspecific protein adsorption and cell association compared with TA-based MPN capsules [33]. Five-fold less protein adsorbed onto PEG-based MPN (1.8 \pm $\left.0.2 \mathrm{ng} \mathrm{mm}^{-2}\right)$ than TA-based MPN $\left(8.6 \pm 0.5 \mathrm{ng} \mathrm{mm}^{-2}\right)$ capsules, as determined by quartz crystal microbalance (QCM) measurements after incubation in $100 \%$ human blood serum for $1 \mathrm{~h}$ at $37{ }^{\circ} \mathrm{C}$. Like the TA-based MPN capsules, the PEG-based MPN capsules can disassemble and release encapsulated cargo at physiologically relevant acidic $\mathrm{pH}(\mathrm{pH} 5)$. 
Hyaluronic acid (HA) has a high binding affinity toward CD44 receptors, which are overexpressed on the cell membranes of many types of cancer cells. Therefore, the incorporation of catechol-functionalized HA into the PEG-based MPN capsules significantly enhanced association with CD44 overexpressing (CD44+) cancer cell lines [34]. HA-based MPN capsules also help control the protein layer, called the "protein corona," which forms on particles when they enter the bloodstream. Ju et al. [35] further investigated the effect of protein coronas on the targeting ability of HA-based MPN capsules (Fig. 6). The HA-based MPN capsules were incubated in human serum at $37{ }^{\circ} \mathrm{C}$ for $1 \mathrm{~h}$ and extensively washed to remove unbound proteins, and the final protein corona was clearly visible in TEM images. The incorporation of HA with higher molecular weight $(51,120$, or $230 \mathrm{kDa})$ enhanced the binding affinity of the capsules toward CD44+ cells, and this enhanced affinity was negligibly affected by the presence of protein coronas. In contrast, the nonspecific interactions of capsules with CD44 minimal expressing (CD44-) cells at $37{ }^{\circ} \mathrm{C}$ were significantly reduced by the presence of protein coronas. Therefore, the targeting specificity of the capsules was enhanced by protein coronas, as the formation of a protein corona decreased the surface energy of capsules and reduced nonspecific interactions with the cell membrane. These results highlight that a protein corona is not always detrimental, but rather can be beneficial, especially in terms of the targeting specificity of certain MPN capsules.

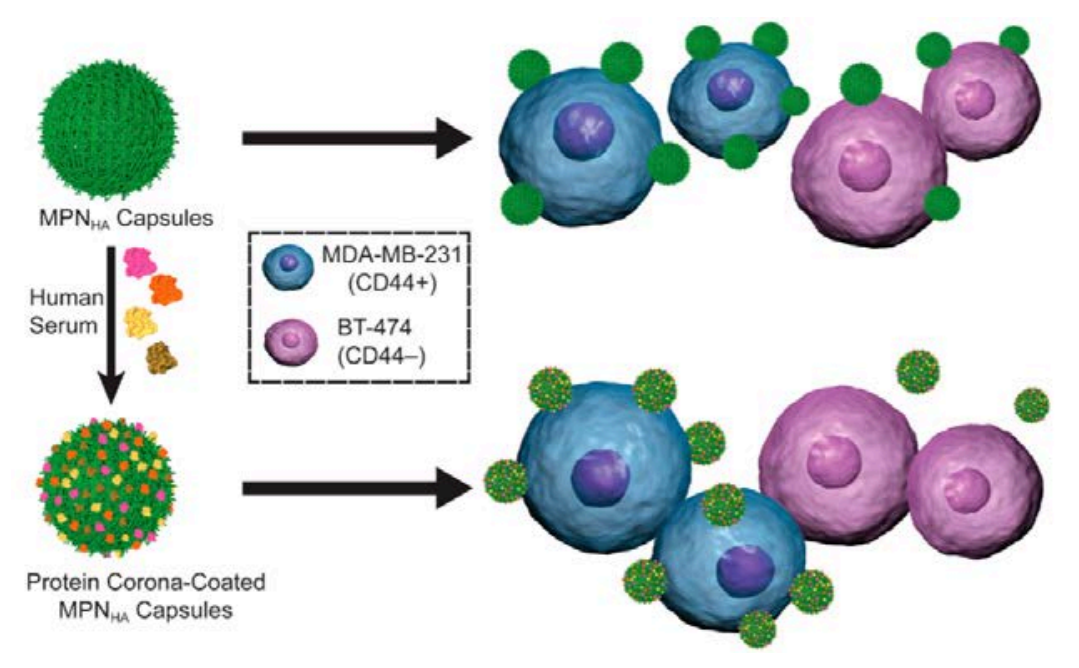


Fig. 6 Schematic illustration of the formation of protein coronas on MPN capsules exposed to human serum, and the association of corona-coated or uncoated MPN capsules with CD44 overexpressing cells (CD44+, blue) and CD44 minimal expressing cells (CD44-, purple). Adapted from ref. [35] with permission from American Chemical Society.

Besides the targeting ability, the stiffness of particles is another dominant factor in determining biodistribution and circulation in vivo [80]. To understand the stiffness of MPN capsules, the mechanical properties were investigated with AFM [81]. A colloidal silica particle was attached to a silicon nitride cantilever by a two part epoxy adhesive, where a small amount of adhesive is spread on a glass slide, the cantilevers lowered into this adhesive, and then the adhesive cantilever is immediately used to pick up a colloidal silica particle from a different location on the glass slide. The MPN capsules were indented with this colloidal probe, taking force-distance curves with an approaching velocity of $100 \mathrm{~nm} \mathrm{~s}^{-1}$. The Reissner's thin shell theory $[82,83]$ was used to determine the modulus of the capsules, where the capsule is compressed by a rigid probe at a given load of $F$, then, $F=k_{\text {shell }} \delta$ in a small deformation regime, where $k_{\text {shell }}$ is the capsule stiffness and $\delta$ is deformation. $k_{\text {shell }}$ can also be written as:

$$
k_{\text {shell }}=\frac{4 E_{s}}{R \sqrt{3\left(1-v^{2}\right)}} h^{2}
$$

where a radius of capsule is $R_{\mathrm{c}}$, a radius of probe is $R_{\mathrm{p}}, 1 / R=1 / R_{\mathrm{c}}+1 / R_{\mathrm{p}}$, shell thickness is $h$, $v$ is the Poisson's ratio of capsule. From this equation, the Young's modulus of the capsule $\left(E_{\mathrm{s}}\right)$ can be estimated. 

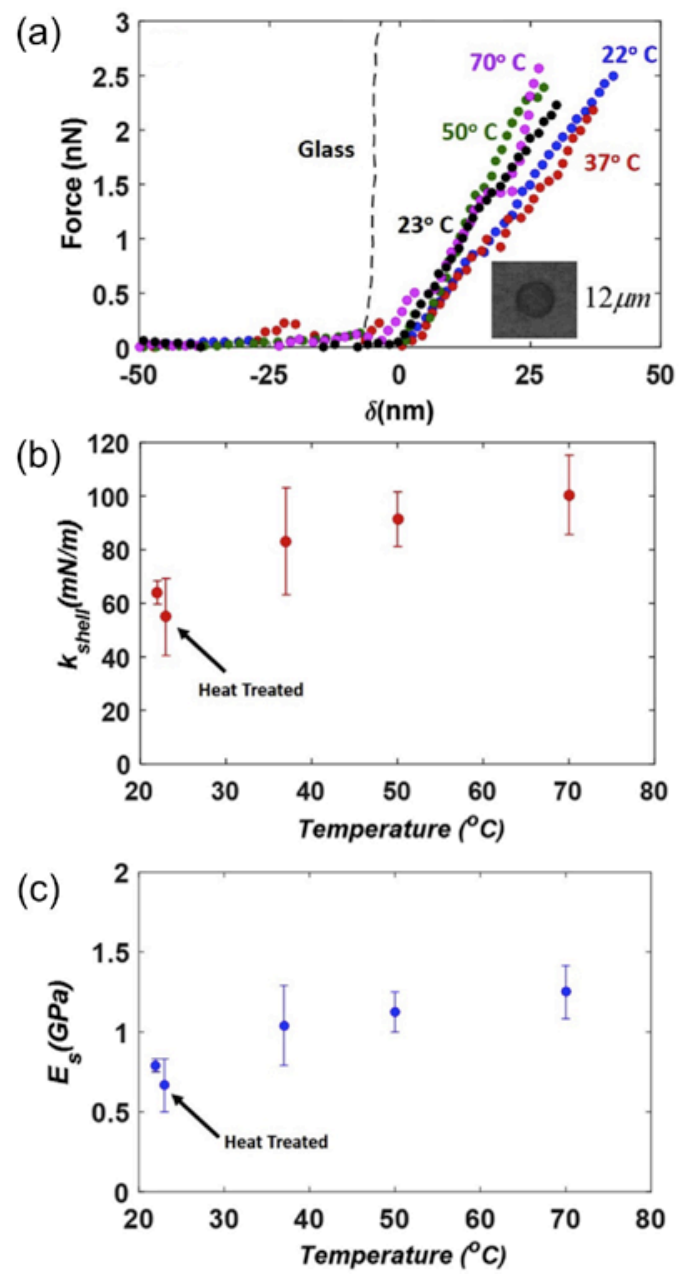

Fig. 7 Mechanical characterization of MPN capsules by AFM compression tests. (a) Forcedeformation curves, (b) the capsule stiffness, and (c) the Young's modulus of water-filled MPN capsules at various temperatures. Adapted from ref. [81] with permission from Elsevier.

The MPN capsules became slightly more rigid with an increase in temperature (Fig. 7), which could allow for unique applications to be realized. Specifically, the $k_{\text {shell }}$ changed from 60 to $100 \mathrm{mN} \mathrm{m}^{-1}$ and the corresponding $E_{\mathrm{s}}$ changed from 0.8 to $1.3 \mathrm{GPa}$ when the temperature increased from room temperature to $70{ }^{\circ} \mathrm{C}$. This could be attributable to the higher stability constants and/or the rearrangement of the network to form more homogeneous structures at higher temperatures. However, the $k_{\text {shell }}$ and $E_{\mathrm{s}}$ of heat-treated 
MPN capsules returned to the initial values, within experimental error, at room temperature. As there was a relatively small temperature effect on the stiffness once returned to room temperature, MPN capsules could be a viable choice where thermal cycling and a temperature independent behavior is favored. 


\section{MPN coatings on nanomaterials}

The deposition of conformal, uniform films on nanomaterials is an important, albeit challenging task. Conformal coatings are important, as the surface functionality and dispersibility of nanomaterials can be controlled with prudent choice of the coating material. MPNs are well suited for coating nanomaterials because the gallol groups in TA work as both high adsorptive and high dispersive groups in water [55]. Moreover, the MPN coating process avoids heat treatment, organic solvents, special instruments, and additive chemicals. MPN coatings on diverse nanomaterials have recently been reported, and representative examples are given below.

The versatility of MPNs even applies to coating 2D materials, such as graphene oxide (GO) nanosheets (Fig. 8) [18]. After coating, the zeta potential of the GO nanosheets shifts from -36 to $-44 \mathrm{mV}$, and the MPN-coated GOs are still highly dispersible and stable in water, and therefore easy to handle. Dynamic light scattering measurements revealed a smaller hydrodynamic diameter after coating, suggesting that the MPN coating mitigates aggregation. Chemical reduction of GO using hydrazine vapor is regularly carried out to remove the epoxy and hydroxyl groups on the GO surface, yielding reduced GO (rGO). This reduction process is still effective for MPN-coated GO and does not degrade the outer MPN layer, thereby resulting in a hydrophilic surface for the MPN-coated rGO, while uncoated rGO have a more hydrophobic surface. The MPN coating and subsequent reduction of GO is an effective two-step route to prepare water-dispersible conductive rGO composites. 


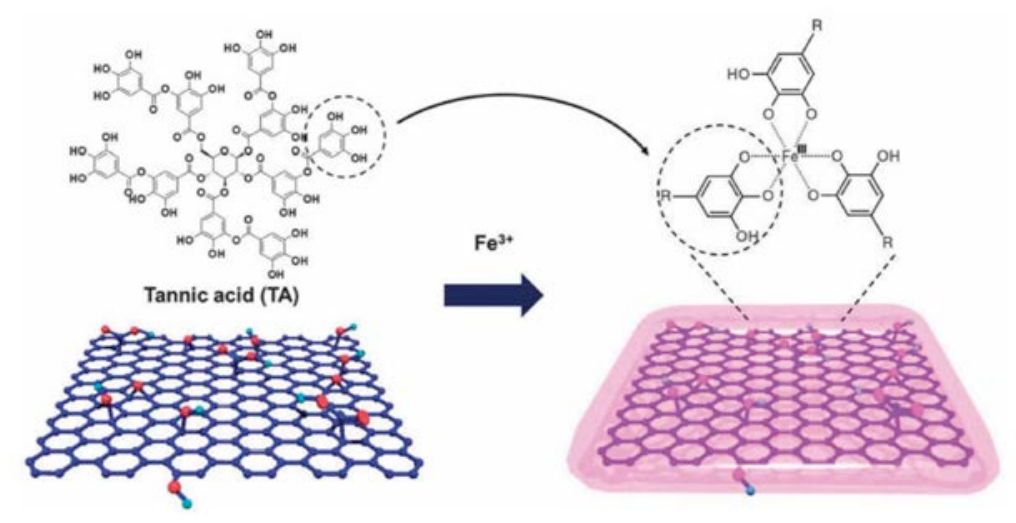

Fig. 8 Schematic illustration of the MPN coating of graphene oxide (GO). Adapted from ref. [18] with permission from PCCP Owner Societies.

Various other nanomaterials can also be coated with MPNs. For example, the photoluminescence from single nitrogen-vacancy defects in nanodiamonds is significantly enhanced by MPN coatings [19]. The fluorescence lifetime of the MPN-coated nanodiamonds becomes shorter ( $\tau=5.5 \pm 1.5 \mathrm{~ns}$ ) than those for uncoated nanodiamonds ( $\tau=$ $8.3 \pm 1.1 \mathrm{~ns}$ ), with the shorter fluorescence lifetime associated with brighter fluorescence. Plausible mechanisms for this enhancement is the reduction of non-radiative components that are often present on the surface of nanodiamonds. Importantly, the photostability, optically detected magnetic resonance signal and emission spectra are not affected by the MPN coating, and fluorescence resonance energy transfer is also unlikely to occur as MPNs do not have any spectral overlap with the nitrogen-vacancy center emission of nanodiamonds.

Nanoparticles other than nanodiamonds also demonstrated enhanced properties after MPN coating. For example, MPN-coated AuNPs [17] show enhanced catalytic performance for the reduction of 4-nitrophenol and improved reusability when compared with uncoated AuNPs [24] (Fig. 9). Zeng and co-workers suggested that the abundant aromatic rings in TA enriched 4-nitrophenol from the aqueous mixture through $\pi-\pi$ interaction, thus giving rise to a local high concentration of 4-nitrophenol, and therefore a higher catalytic activity. MPN- 
coated AuNPs can be easily isolated from the reaction mixture by centrifugation, and then reused in the next catalytic cycle. TEM images confirmed the unchanged morphology of MPN-coated AuNPs after numerous catalytic cycles. Considering the versatility and simplicity of MPN coatings, this approach should be applicable to nanoparticle systems other than GO, nanodiamonds, and AuNPs.

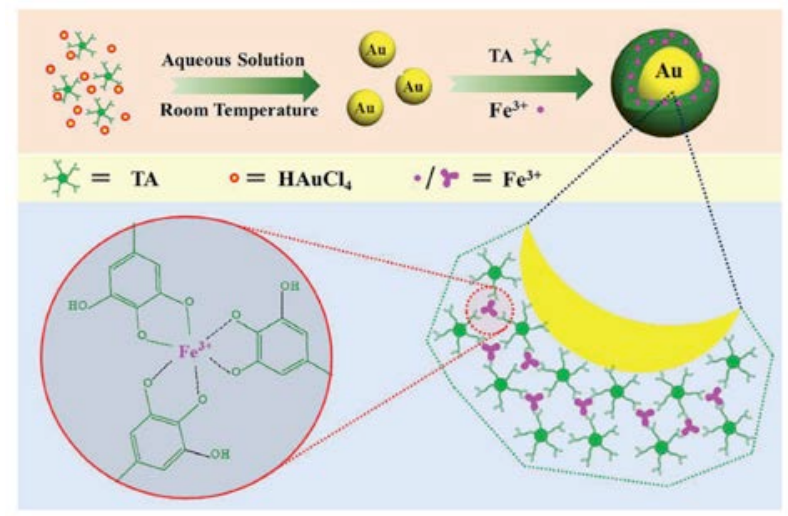

Fig. 9 Schematic illustration of an MPN coating on gold nanoparticles. Adapted from ref. [24] with permission from Royal Society of Chemistry.

The uniform coating of MPNs allows for complex assemblies to be constructed based on the responsive chelation capacity of the incorporated TA. For example, MPN coatings can transform a wide range of objects, including micro-/nanoparticles, nanowires, nanosheets, nanocubes, and even cells, into modular bricks for superstructuring [55] (Fig. 10). The interactions between phenolic groups and substrates, as supported by AFM studies and molecular dynamics simulation, result in robust particle interlocking after contact. This method displays significant versatility in the choice of building blocks, thus providing a novel platform for the rapid generation of superstructured assemblies across a wide range of length scales, from nanometers to centimeters. This highlights that MPNs are not only applicable as a building block of functional materials, but can also be used to transform diverse objects into building blocks. 

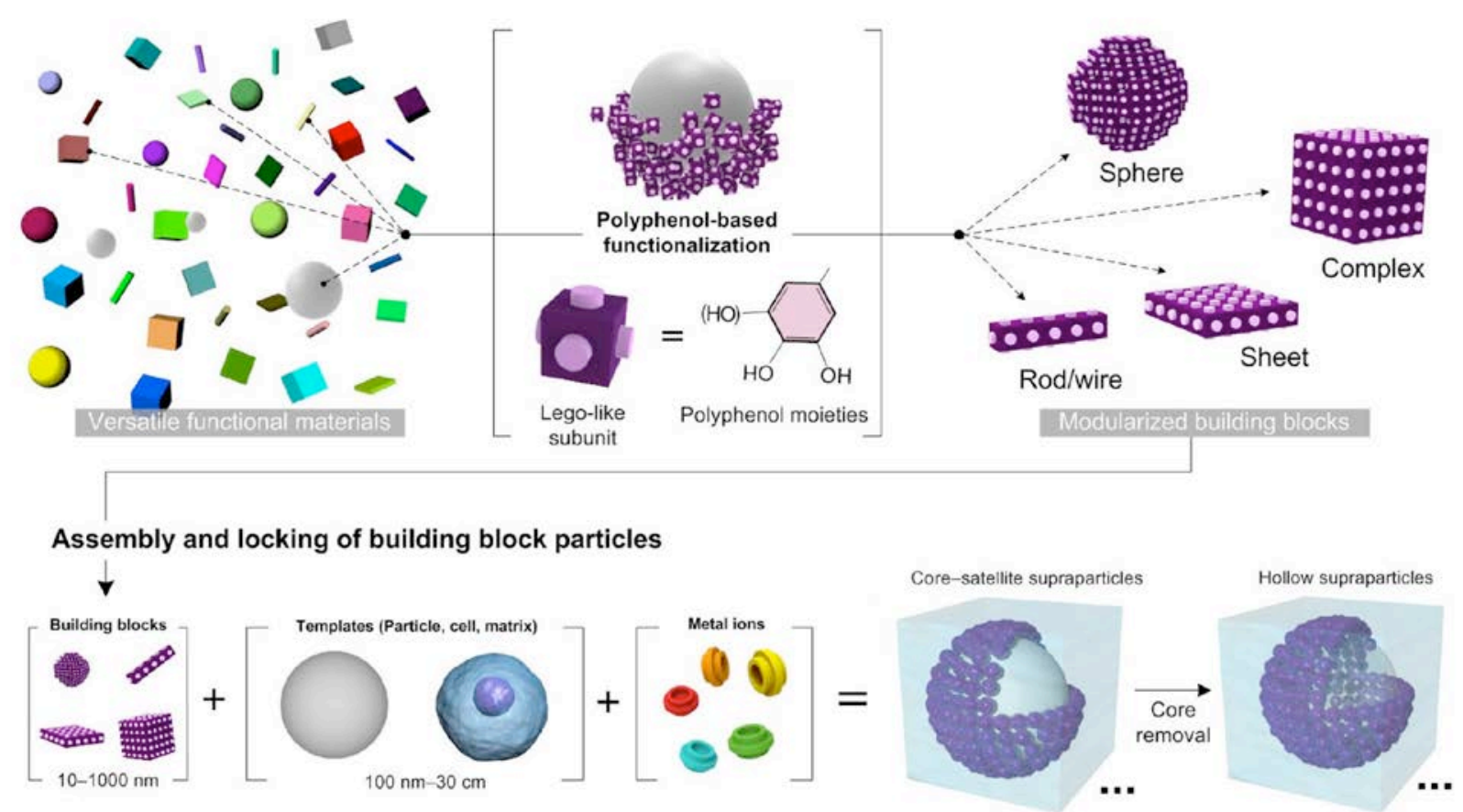

Fig. 10 Schematic illustration of Lego-inspired modularization of building blocks through MPN coating and their superstructure formation. Adapted from ref. [55] with permission from Nature Publishing Group. 


\section{MPN coatings at biointerfaces}

TA is useful for biological applications, as it is generally recognized as safe (GRAS) by the FDA and is commonly utilized as a food additive in many parts of the world. More specifically, the human tolerable daily intake of TA is known to be $13.6 \mathrm{~g} / 60 \mathrm{~kg}$ [84]. Considering this high biocompatibility, MPNs are an appropriate choice as coating agents for various biointerfaces. For example, the surfaces of bacteria, yeast, animal cells, viruses, and even teeth have been coated with MPNs (Table 1). The aim of these coatings range from dental hypersensitivity treatment [20,41] to cytoprotection [21] and cellular surface functionalization [39]. The details of each example are described below.

MPN coatings were applied as a rapid, effective and user-friendly method to mitigate dental hypersensitivity by Hwang and co-workers [20, 41]. Human teeth are primarily composed of mineralized hydroxyapatite (HA)-containing enamel and less mineralized HAcontaining dentin with dentinal tubules (Fig. 11). Adults can experience frequent sharp pains (dental hypersensitivity) derived from fluid flow when they have exposed dentinal tubules. In clinics, a polymerizable sealant consisting of glutaraldehyde and (hydroxyethyl)methacrylate is widely used to occlude the exposed dentinal tubules and prevent pain, but this can only be performed after recommendation from a doctor due to the toxicity of glutaraldehyde. Therefore, MPNs were explored as a safe and alternative dental sealant. Selective deposition is favorable from a cosmetic point of view and after dipping teeth into an MPN solution for only 4 min, the dentin color changed to purple (Fig. 11c), which is the typical color of the $\mathrm{Fe}^{\mathrm{III}}$-TA complex, while the surrounding enamel remained white. This suggested that the MPN predominantly deposited on the dentin, which has a higher protein content than enamel, and SEM observation of the tooth slice showed that the tubule entrances were narrowed and occluded after MPN deposition (Fig. 11d). Moreover, the MPN coating was mechanically stable as confirmed by applying 1,000 strokes at $200 \mathrm{~g}$ force $\left(60\right.$ strokes $\mathrm{min}^{-1}$ ) of tooth 
brushing. The MPN coating also helped repair teeth by inducing the remineralization of HA in the tubules by gallol-mediated $\mathrm{Ca}^{2+}$ absorption during incubation in artificial saliva for 7 days.

There are numerous advantages of an MPN-based desensitizer over the commercial glutaraldehyde-based sealants. MPN coatings are rapid to form and efficient in occluding tubules. Moreover, they show low cytotoxicity and good adhesion to human periodontal ligament cells, which reduce further dentin exposure to the outside environment. The MPN coating procedure is facile and not greatly reliant on a user's skill. Finally, the mechanical robustness of MPNs is encouraging because the oral environment is often under a variety of mechanical stresses such as chewing, brushing, and temperature-driven air pressure. Taken together, Hwang et al. [20] stated that the MPN coating can be a promising "at-home" desensitizer product, similar in ease to tooth paste and mouthwash.
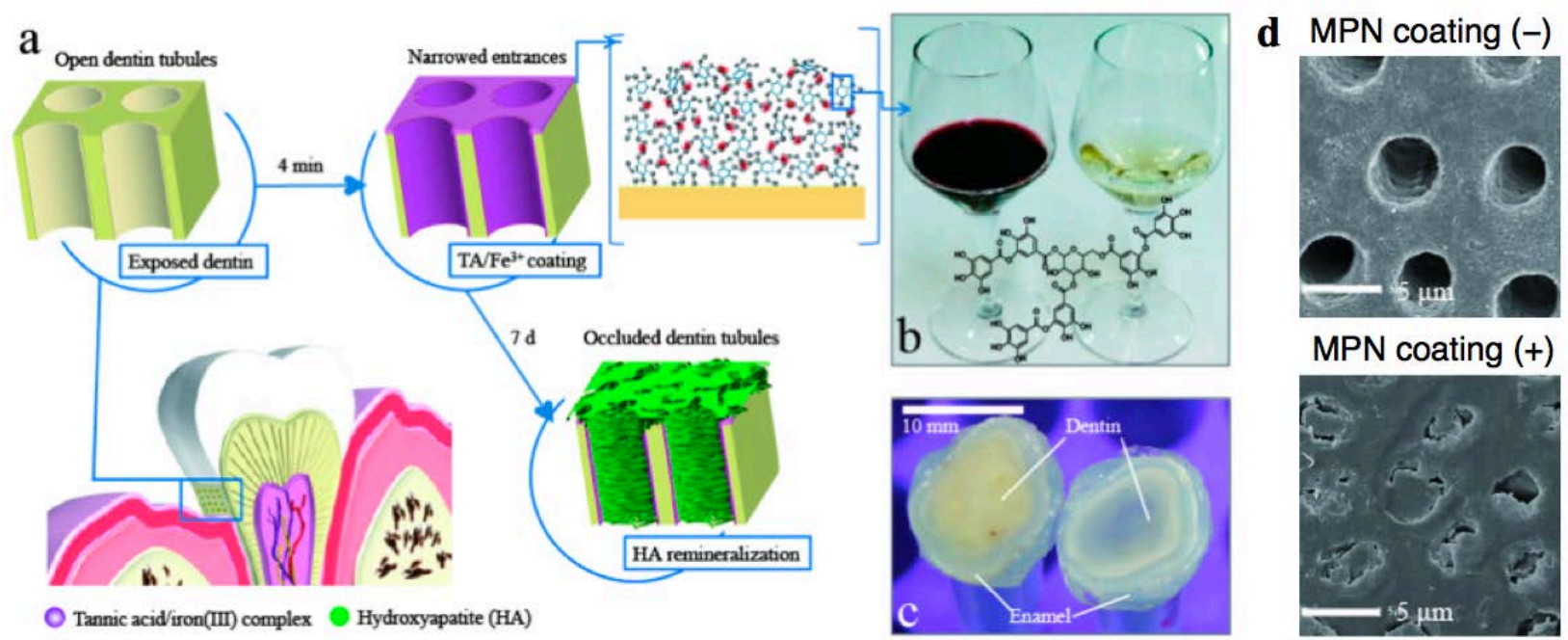

Fig. 11 The MPN-based dentin desensitizer. (a) A schematic of the MPN-mediated desensitizing process for occluding exposed dentinal tubules. (b) Wine has a high TA content. (c) The dentin color changes to a light purple after MPN coating. (d) SEM images of the dentinal tubules of human teeth before and after MPN deposition. Adapted from ref. [20] with permission of Nature Publishing Group. 
Non-mineralized biointerfaces can also be coated by MPNs, as Park et al. [21] demonstrated the coating of S. cerevisiae (yeast) with MPNs for cytoprotection (Fig. 12). Li et al. [39] also coated living cells including yeast with MPNs to engineer the cellular surfaces. The successful MPN coating was confirmed by Raman spectroscopy, zeta-potential changes, SEM, and TEM. Mitochondrial activity of the MPN-coated yeast remained as high as $98 \pm 2.5 \%$ of the uncoated yeast, indicating the unprecedented cytocompatibility of MPN encapsulation [21]. Similar levels of viability ( 95\%) was also reported for both yeast and $E$. coli by Li and co-workers [39]. Moreover, MPNs can act as a primary layer for secondary modifications by exploiting the versatile reactivity of the constituent phenolics to both thiols and amines, and MPN-coated cellular surfaces can be further modified with magnetic nanoparticles, DNA, and MRI contrast agents [39]. 
(a)

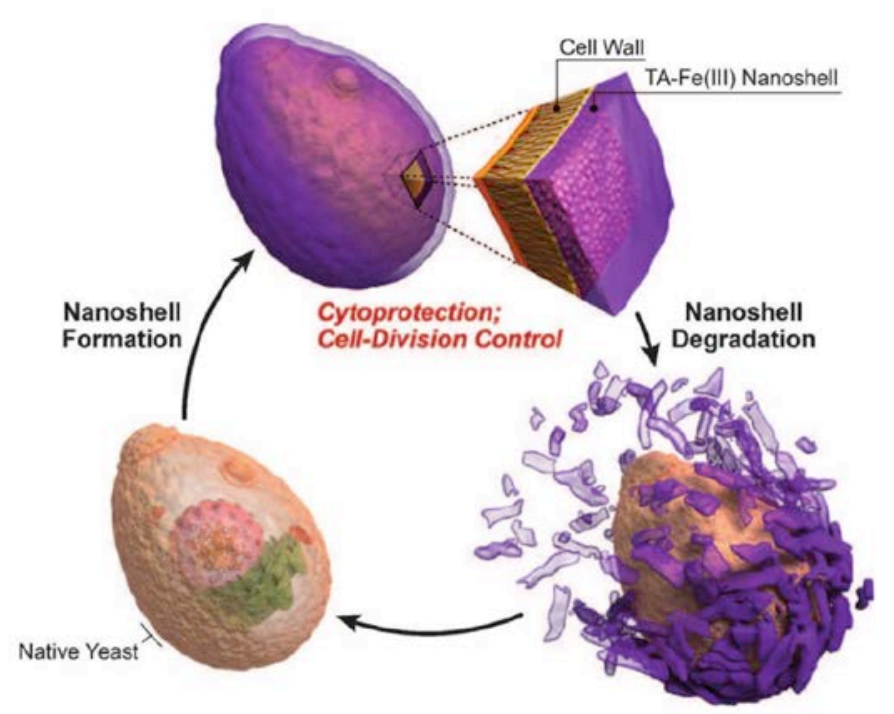

(b)
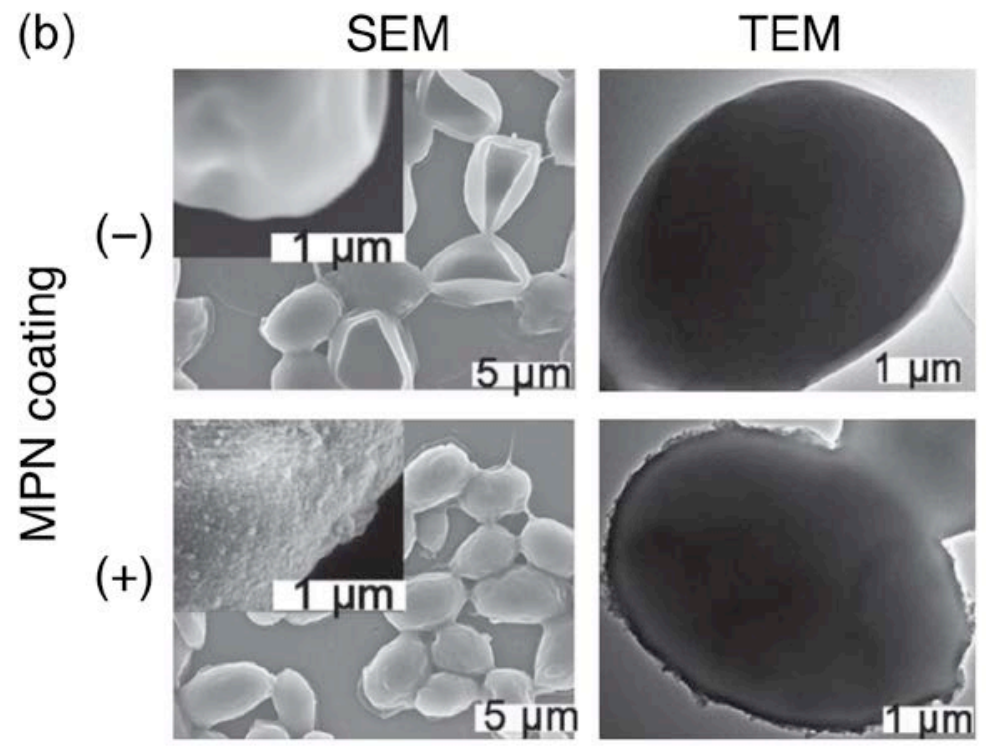

Fig. 12 (a) Schematic representation of an MPN coating on an individual yeast cell. Adapted from ref. [21] with permission of John Wiley and Sons. (b) Scanning electron microscope (SEM) and transmission electron microscope (TEM) images of the yeast cells before and after MPN coating. Adapted from ref. [21] with permission of John Wiley and Sons.

The MPN shell not only acts as a primary layer for surface functionalization, but also suppresses the cell division of yeast in a method similar to the natural sporulation process. The number of colony-forming units (CFU) can be calculated by spreading MPN-coated and uncoated yeast cells on agar plates, where values of $3.0 \times 10^{4}$ and $1.3 \times 10^{7} \mathrm{CFU} \mathrm{mL}^{-1}$ were 
observed for MPN-coated and uncoated yeast, respectively [21]. This is roughly a three-order of magnitude decrease in cellular division activity when compared against uncoated cells. Similarly, the division rate, which is defined as the time point when $\operatorname{lnOD}_{600}$ reaches -2 , was delayed from $\sim 9 \mathrm{~h}$ (uncoated yeast) to $\sim 26 \mathrm{~h}$ (MPN-coated yeast) when the yeast was cultured in solution. Reduced transport of nutrients combined with the rigidity of the MPN shell could be causes for the retardation of cell division. The MPN-coated cells eventually divided by rupturing the surrounding stiff MPN layer [39]. As the degree of division suppression is larger in the solid-phase culture than in the solution-phase culture, the MPN coating is thought to act as a physical barrier to prevent MPN-coated cells from contacting the solidstate nutrients of the culture plate. Qu et al. [39] also showed that an MPN coating places the cells in the dormant state, thereby prolonging viability. For example, when the uncoated yeast cells were stored in water, they lost their viability within 15 days, while approximately $70 \%$ of the MPN-coated cells were still alive at the same time point (i.e., 15 days).

During natural sporulation, a robust proteinaceous shell forms over the cell wall while the metabolic activity is concurrently shut down, so that the organism can survive in stressful conditions such as UV radiation, desiccation, osmotic pressure, shear force, nutrient deprivation, extreme temperature, and toxic chemicals [85]. Inspired by this natural survival mechanism, artificially encasing living cells, including both spore-forming and non-sporeforming, has been explored (artificial spores) [86-88]. However, a cytocompatible coating that fully mimics the germination process (i.e., spore disassembly on-demand) had been lacking until recently. Natural spores can disassemble when the spore's inner membrane senses the end of unfavorable environmental conditions, thereby resuming cellular proliferation (i.e., germination). MPNs mimic the triggered disassembly seen with natural sporulation, as MPNs can respond to slight $\mathrm{pH}$ changes and disassemble under cytocompatible conditions. MPN coatings can be disassembled, and the cell division rate 
returned to the native level seen with uncoated cells, by treating the MPN-coated yeast cells with $20 \mathrm{mM} \mathrm{HCl} \mathrm{[21]} \mathrm{or} \mathrm{phosphate-buffered} \mathrm{saline} \mathrm{(PBS)} \mathrm{containing} 7.5 \mathrm{mM}$ ethylenediaminetetraacetic acid (EDTA) [39]. Another important attribute that synthetic sporulation coatings should have is protection from varied harsh environments. For example, when yeast cells are irradiated with UV light (254 nm) with $8 \mathrm{~J}$ of light power, only $8 \pm 1 \%$ of uncoated yeast survive, while $73 \pm 2 \%$ of the MPN-coated cells remain viable [21]. Moreover, the MPN-coating increases the yeast's tolerance to lethal lytic enzymes and silver nanoparticles [21]. Finally, the intracellular level of reactive oxygen species (ROS) is lower in the MPN-coated yeast cells than the uncoated cells, as revealed by the 2',7'dichlorofluorescein diacetate assay [39].

The yeast cell wall mainly consists of rigid polysaccharides (mannoproteins, $\beta$ glucans and chitins) [89], while mammalian cells are encased with lipid bilayer membranes that are much more fragile. Nonetheless, mammalian cells including HeLa, NIH 3T3, Jurkat and PC12 cells can be successfully coated with MPNs [38, 39]. The viability of mammalian cells is dependent on the $\mathrm{Fe}^{\mathrm{III}}$ concentration used, and the viabilities of these cell lines were all above $80 \%$. The viabilities of MPN-coated cells is higher than silica-coated cells [90], again suggesting that MPNs are highly cytocompatible. Moreover, MPN coatings confer mechanical durability to the cells, and MPN-coated HeLa, NIH 3T3 and Jurkat cells maintained their spherical shape during SEM observations, whereas uncoated cells ruptured due to dehydration in the reduced pressure of the imaging chamber. Like what is seen for yeast, the MPN coating provides mammalian cells with a resistance to harmful conditions such as UV irradiation and cytotoxic cationic polymers. By treating MPN-coated HeLa cells with 0.5 mM EDTA-containing Dulbecco's modified eagle medium, the coating could be disassembled and the proliferation rate of HeLa cells restored back to that of uncoated cells [38]. 
Recently, demand for cell-based applications (e.g., bioelectronic devices, biocatalysis, bioproduction, biosensors, and therapies) has been increasing. Because these cell-based technologies require long-term cell viability, and functionality in unfriendly environments, single-cell based cytoprotective coating techniques will continue to attract attention. In this regard, MPN coatings hold numerous advantages, as they can protect and regulate cells, while also allowing for on-demand disassembly to recover the original properties of the cells. Moreover, MPN coatings can act as a primary coating for secondary modification, greatly expanding the potential of this technique. Therefore, the importance of MPN coatings in the fields of single-cell-based technology is expected to grow.

\section{Conclusions and outlook}

This review highlights some of the recent advances in the MPN coating of nanomaterials and biointerfaces. While this approach is only in its infancy, a diverse array of MPN-coated objects (including graphene, nanodiamonds, AuNPs, yeast, mammalian cells, teeth) have been coated. However, there is still significant space for improving and expanding upon the choice of phenolic ligands used for MPN construction. Commercially available TA is in fact a mixture of gallotannins and other galloylated glucopyranoses extracted from plants, and the total synthesis of decagalloylglucose commonly used to represent TA (the chemical structure shown in Fig. 1), has just recently accomplished [91]. This total synthesis of the representative TA molecule should enable more detailed investigations into the stoichiometry of metal ions and gallol groups, which may assist with elucidation of the MPN structures. Additionally, a TA-inspired gallol-functionalized polymer, polyvinylgallol, has also been synthesized recently [92] through reversible addition-fragmentation chain transfer polymerization. Polyvinylgallol is a promising synthetic analogue of TA for MPN 
preparation, and similar synthetic molecules will likely be introduced in the near future to afford additional functionalities and unique routes for post-modification.

The high versatility of MPN coatings can be used in conjunction with the sacrificialtemplate-mediated approach to yield multifunctional responsive capsules, which show promise as catalytic materials, imaging agents, and biomedical delivery agents. The nonspecific interaction of natural polyphenols with biological systems [93] can have a negative impact on certain biomedical applications, such as intravenous drug delivery, although polyphenols are regularly ingested and therefore drug delivery routes other than intravenous delivery are also possible. Due to the modular approach of engineering MPNs, functionalization or construction with low-fouling synthetic moieties like PEG-polyphenol [33], targeting moieties like HA-polyphenol [34] or antibody-polyphenol, and even conjugation and incorporation of phenolic drugs like quercetin, should become commonplace and address issues facing certain biomedical applications of MPNs. For other applications, such as cell-coating, the highly fouling nature of most MPNs offers a unique advantage over many synthetic routes that result in lower surface coverages due to their lack of ubiquitous binding. Therefore, future pursuits should be guided by harnessing the inherent properties of MPNs, such as ubiquitous coating, modularity, ease of functionalization, and metal or polyphenol-derived functionality to engineer coatings for specific applications. In summary, the simple coating protocol of MPNs in combination with their low toxicity and reversible assembly/disassembly characteristics make them highly relevant for biological use. We expect that further development will establish MPN coatings as a platform technology for cell-based fundamental research and advanced biomedical applications, as well as material assembly and superstructuring.

\section{Acknowledgment}


This research was supported by the Australian Research Council Centre of Excellence in Convergent Bio-Nano Science and Technology (project number CE140100036). 


\section{Author Biographical Sketches:}

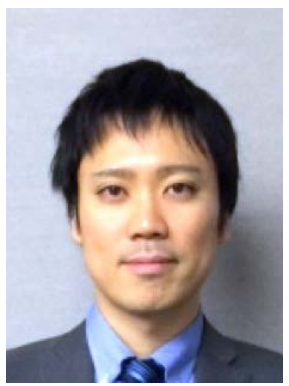

Hirotaka Ejima was born in Kanagawa Prefecture, Japan in 1983. He completed his PhD under Professor T. Serizawa in 2011 at The University of Tokyo. He then joined the research group of Professor F. Caruso at The University of Melbourne as a JSPS postdoctoral fellow. After spending two and a half years in Australia, he moved back to Japan, working in the research group of Professor N. Yoshie at the Institute of Industrial Science, The University of Tokyo. His current research interests are in developing functional nanomaterials based on renewable bioresources.

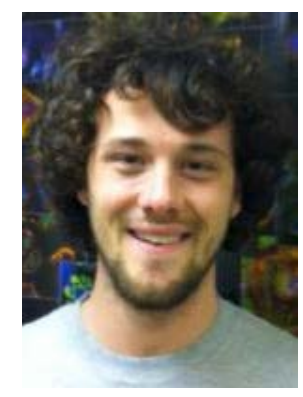

Joseph J. Richardson was born in the 'Sunshine State' Florida, USA in 1988. He received his Bachelor's degree in Philosophy and his Master's in Industrial and Systems Engineering from the University of Florida. J.J. completed his $\mathrm{PhD}$ in early 2015 researching thin film deposition strategies under the supervision of Professor F. Caruso at The University of Melbourne. Currently, he is a Postdoctoral Fellow at CSIRO studying metal-organic hybrid systems for biomedicine. 


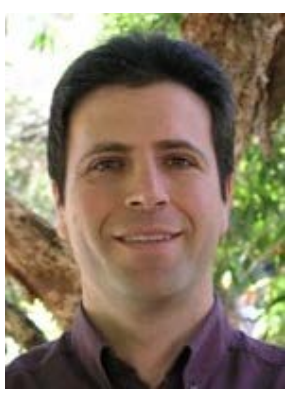

Frank Caruso is a professor and ARC Australian Laureate Fellow at the University of Melbourne. He received his PhD degree in 1994 from the University of Melbourne, and then moved to the CSIRO Division of Chemicals and Polymers in Melbourne. He was an Alexander von Humboldt Research Fellow and then group leader at the Max Planck Institute of Colloids and Interfaces from 1997-2002. His research interests focus on developing advanced nano- and biomaterials for biotechnology and medicine. 
Graphical abstract:

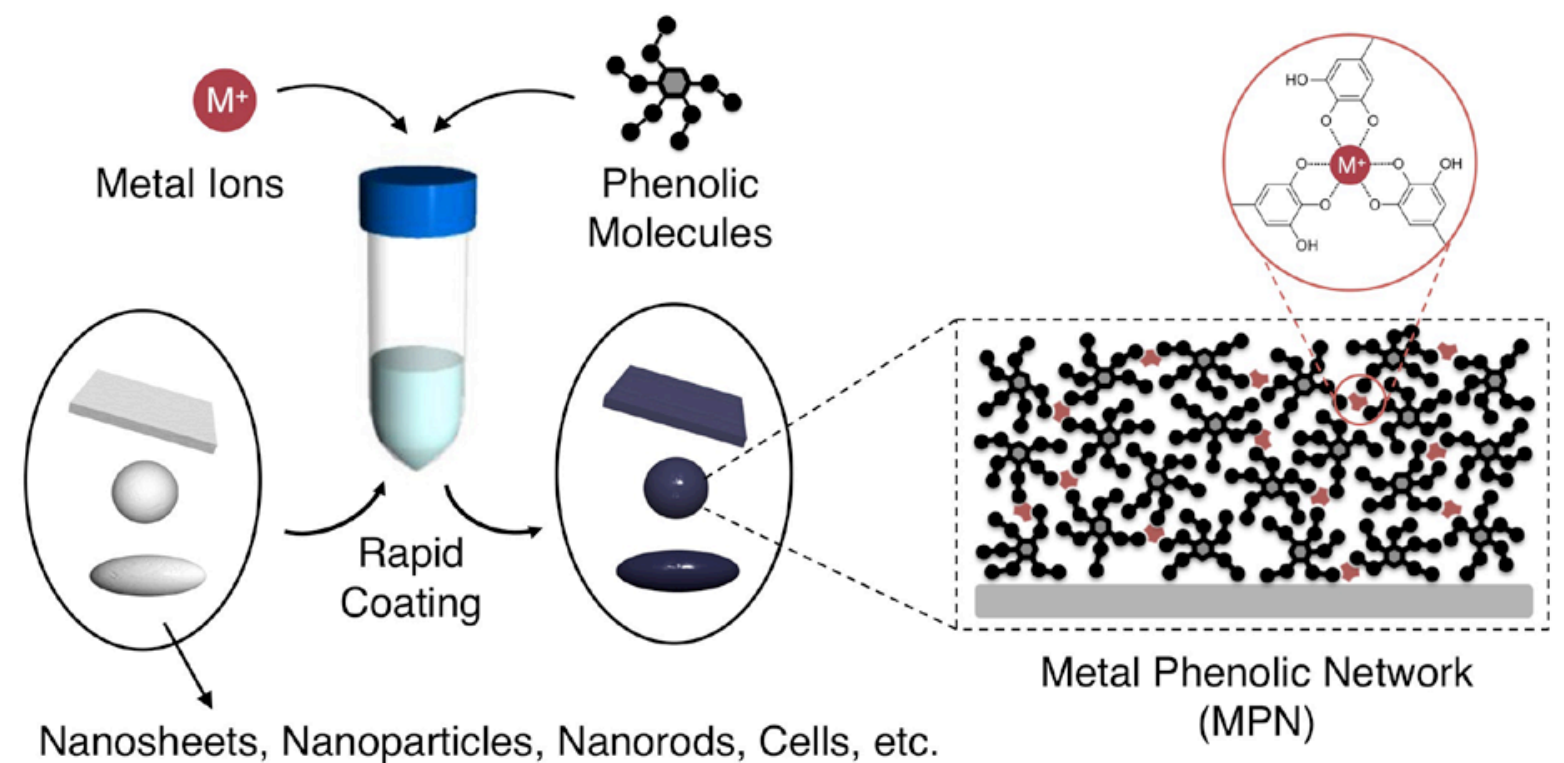




\section{References}

[1] J.C. Love, L.A. Estroff, J.K. Kriebel, R.G. Nuzzo, G.M. Whitesides, Chem. Rev. 105 (2005) 1103-1170.

[2] L. Dykman, N. Khlebtsov, Chem. Soc. Rev. 41 (2012) 2256-2282.

[3] J.M. Harris, N.E. Martin, M. Modi, Clin. Pharmacokinet. 40 (2001) 539-551.

[4] C. Haensch, S. Hoeppener, U.S. Schubert, Chem. Soc. Rev. 39 (2010) 2323-2334.

[5] C. Queffélec, M. Petit, P. Janvier, D.A. Knight, B. Bujoli, Chem. Rev. 112 (2012) 37773807.

[6] K.D. Demadis, M. Papadaki, R.G. Raptis, H. Zhao, Chem. Mater. 20 (2008) 4835-4846.

[7] Q. Wei, R. Haag, Mater. Horiz. 2 (2015) 567-577.

[8] K. Ariga, J.P. Hill, Q.M. Ji, Phys. Chem. Chem. Phys. 9 (2007) 2319-2340.

[9] J.J. Richardson, M. Björnmalm, F. Caruso, Science 348 (2015) aaa2491.

[10] Y. Wang, A.S. Angelatos, F. Caruso, Chem. Mater. 20 (2008) 848-858.

[11] H. Lee, S.M. Dellatore, W.M. Miller, P.B. Messersmith, Science 318 (2007) 426-430.

[12] S. Hong, Y.S. Na, S. Choi, I.T. Song, W.Y. Kim, H. Lee, Adv. Funct. Mater. 22 (2012) 4711-4717.

[13] J.H. Waite, M.L. Tanzer, Science 212 (1981) 1038-1040.

[14] G.P. Maier, M.V. Rapp, J.H. Waite, J.N. Israelachvili, A. Butler, Science 349 (2015) 628-632.

[15] T.H. Anderson, J. Yu, A. Estrada, M.U. Hammer, J.H. Waite, J.N. Israelachvili, Adv. Funct. Mater. 20 (2010) 4196-4205.

[16] V. Ball, D. Del Frari, V. Toniazzo, D. Ruch, J. Colloid Interfaces Sci. 386 (2012) 366372.

[17] H. Ejima, J.J. Richardson, K. Liang, J.P. Best, M.P. van Koeverden, G.K. Such, J. Cui, F. Caruso, Science 341 (2013) 154-157.

[18] H. Ozawa, M. Haga, Phys. Chem. Chem. Phys. 17 (2015) 8609-8613.

[19] K. Bray, R. Previdi, B.C. Gibson, O. Shimoni, I. Aharonovich, Nanoscale 7 (2015) 4869-4874.

[20] D.X. Oh, E. Prajatelistia, S.W. Ju, H.J. Kim, S.J. Baek, H.J. Cha, S.H. Jun, J.S. Ahn, D.S. Hwang, Sci. Rep. 5 (2015).

[21] J.H. Park, K. Kim, J. Lee, J.Y. Choi, D. Hong, S.H. Yang, F. Caruso, Y. Lee, I.S. Choi, Angew. Chem. Int. Ed. 53 (2014) 12420-12425.

[22] M.A. Rahim, H. Ejima, K.L. Cho, K. Kempe, M. Müllner, J.P. Best, F. Caruso, Chem. Mater. 26 (2014) 1645-1653.

[23] R. Liu, A. Xu, RSC Adv. 4 (2014) 40390-40395.

[24] T. Zeng, X. Zhang, Y. Guo, H. Niu, Y. Cai, J. Mater. Chem. A 2 (2014) 14807-14811.

[25] J. Guo, Y. Ping, H. Ejima, K. Alt, M. Meissner, J.J. Richardson, Y. Yan, K. Peter, D.

von Elverfeldt, C.E. Hagemeyer, Angew. Chem. Int. Ed. 53 (2014) 5546-5551.

[26] C. Yang, H. Wu, X. Yang, J. Shi, X. Wang, S. Zhang, Z. Jiang, ACS Appl. Mater. Interfaces 7 (2015) 9178-9184.

[27] Y. Wang, Y. Zhang, C. Hou, F. He, M. Liu, New J. Chem. 40 (2016) 781-788.

[28] M.A. Rahim, K. Kempe, M. Müllner, H. Ejima, Y. Ju, M.P. van Koeverden, T. Suma, J.A. Braunger, M.G. Leeming, B.F. Abrahams, F. Caruso, Chem. Mater. 27 (2015) 58255832.

[29] Y. Ping, J. Guo, H. Ejima, X. Chen, J.J. Richardson, H. Sun, F. Caruso, Small 11 (2015) 2032-2036.

[30] B. Li, L. Guan, K. Wang, D. Zhang, W. Wang, F. Liu, J. Appl. Polym. Sci. 132 (2016) 42865. 
[31] E.D. Bartzoka, H. Lange, K. Thiel, C. Crestini, ACS Sustainable Chem. Eng. (2016) DOI: 10.1021/acssuschemeng.1026b00904.

[32] H. Liang, J. Li, Y. He, W. Xu, S. Liu, Y. Li, Y. Chen, B. Li, ACS Biomater. Sci. Eng. 2 (2016) 317-325.

[33] Y. Ju, J. Cui, M. Müllner, T. Suma, M. Hu, F. Caruso, Biomacromolecules 16 (2015) 807-814.

[34] Y. Ju, J. Cui, H. Sun, M. Müllner, Y. Dai, J. Guo, N. Bertleff-Zieschang, T. Suma, J.J. Richardson, F. Caruso, Biomacromolecules 17 (2016) 2268-2276.

[35] Y. Ju, Q. Dai, J. Cui, Y. Dai, T. Suma, J.J. Richardson, F. Caruso, ACS Appl. Mater. Interfaces 8 (2016) 22914-22922.

[36] S. Kim, S. Philippot, S. Fontanay, R.E. Duval, E. Lamouroux, N. Canilho, A. Pasc, RSC Adv. 5 (2015) 90550-90558.

[37] G. Shen, R. Xing, N. Zhang, C. Chen, G. Ma, X. Yan, ACS Nano 10 (2016) 5720-5729. [38] J. Lee, H. Cho, J. Choi, D. Kim, D. Hong, J.H. Park, S.H. Yang, I.S. Choi, Nanoscale 7 (2015) 18918-18922.

[39] W. Li, W. Bing, S. Huang, J. Ren, X. Qu, Adv. Funct. Mater. 25 (2015) 3775-3784. [40] L. Delalande, I. Tsvetkova, C. Zeng, K. Bond, M. Jarrold, B. Dragnea, Nanoscale 8 (2016) 16221-16228.

[41] E. Prajatelistia, S.W. Ju, N.D. Sanandiya, S.H. Jun, J.S. Ahn, D.S. Hwang, Adv. Healthc. Mater. 5 (2016) 919-927.

[42] P. Han, J. Shi, T. Nie, S. Zhang, X. Wang, P. Yang, H. Wu, Z. Jiang, ACS Appl. Mater. Interfaces 8 (2016) 8076-8085.

[43] C. Yang, H. Wu, J. Shi, X. Wang, J. Xie, Z. Jiang, Ind. Eng. Chem. Res. 53 (2014) 12665-12672.

[44] Q. Song, W. Zhao, H. Yin, H. Lian, RSC Adv. 5 (2015) 63896-63902.

[45] S. Kim, D.S. Kim, S.M. Kang, Bull. Korean Chem. Soc. 36 (2015) 9-10.

[46] S. Kim, T. Gim, S.M. Kang, ACS Appl. Mater. Interfaces 7 (2015) 6412-6416.

[47] S. Kim, S. Kwak, S. Lee, W.K. Cho, J.K. Lee, S.M. Kang, Chem. Commun. 51 (2015)

5340-5342.

[48] S. Çakar, N. Güy, M. Özacar, F. Fındık, Electrochim. Acta 209 (2016) 407-422.

[49] M. Hu, Y. Ju, K. Liang, T. Suma, J. Cui, F. Caruso, Adv. Funct. Mater. 26 (2016) 58275834.

[50] J. Wu, Z. Wang, W. Yan, Y. Wang, J. Wang, S. Wang, J. Membr. Sci. 496 (2015) 58-69. [51] C. Dong, Z. Wang, J. Wu, Y. Wang, J. Wang, S. Wang, Desalination (2016) DOI: 10.1016/j.desal.2016.1006.1034.

[52] H.J. Kim, D.G. Kim, H. Yoon, Y.S. Choi, J. Yoon, J.C. Lee, Adv. Mater. Interfaces 2 (2015) 1500298.

[53] J. Wei, Y. Liang, Y. Hu, B. Kong, G.P. Simon, J. Zhang, S.P. Jiang, H. Wang, Angew. Chem. Int. Ed. 128 (2016) 1377-1381.

[54] S. Huang, X. Li, Y. Jiao, J. Shi, Ind. Eng. Chem. Res. 54 (2015) 1842-1848.

[55] J. Guo, B.L. Tardy, A.J. Christofferson, Y. Dai, J.J. Richardson, W. Zhu, M. Hu, Y. Ju, J. Cui, R.R. Dagastine, I. Yarovsky, F. Caruso, Nat. Nanotechnol. (2016) DOI:

10.1038/NNANO.2016.1172.

[56] R.K. Feller, A.K. Cheetham, Solid State Sci. 8 (2006) 1121-1125.

[57] N.T.T. Nguyen, H. Furukawa, F. Gándara, C.A. Trickett, H.M. Jeong, K.E. Cordova, O.M. Yaghi, J. Am. Chem. Soc. 137 (2015) 15394-15397.

[58] T.J. Kim, J.L. Silva, M.K. Kim, Y.S. Jung, Food Chem. 118 (2010) 740-746.

[59] K.T. Chung, Z. Lu, M.W. Chou, Food Chem. Toxicol. 36 (1998) 1053-1060.

[60] H. Hayatsu, S. Arimoto, T. Negishi, Mutat. Res. 202 (1988) 429-446. 
[61] H. Mukhtar, M. Das, W.A. Khan, Z.Y. Wang, D.P. Bik, D.R. Bickers, Cancer Res. 48 (1988) 2361-2365.

[62] W.E. Bentley, G.F. Payne, Science 341 (2013) 136-137.

[63] S. Quideau, D. Deffieux, C. Douat-Casassus, L. Pouysegu, Angew. Chem. Int. Ed. 50 (2011) 586-621.

[64] T.S. Sileika, D.G. Barrett, R. Zhang, K.H.A. Lau, P.B. Messersmith, Angew. Chem. Int. Ed. 52 (2013) 10766-10770.

[65] S. Hong, J. Yeom, I.T. Song, S.M. Kang, H. Lee, H. Lee, Adv. Mater. Interfaces 1 (2014) 1400113.

[66] E.H. Jeong, J.H. Ryu, H. Jeong, B. Jang, H.Y. Lee, S. Hong, H. Lee, H. Lee, Chem. Commun. 50 (2014) 13388-13390.

[67] C. Dhand, S. Harini, M. Venkatesh, N. Dwivedi, A. Ng, S. Liu, N.K. Verma, S.

Ramakrishna, R.W. Beuerman, X.J. Loh, ACS Appl. Mater. Interfaces 8 (2016) 1220-1232.

[68] X.R. Song, S.X. Yu, G.X. Jin, X. Wang, J. Chen, J. Li, G. Liu, H.H. Yang, Small 12 (2016) 1506-1513.

[69] S. Huang, Y. Zhang, J. Shi, W. Huang, ACS Sustainable Chem. Eng. 4 (2016) 676-681.

[70] J. Li, S. Wu, C. Wu, L. Qiu, G. Zhu, C. Cui, Y. Liu, W. Hou, Y. Wang, L. Zhang,

Nanoscale 8 (2016) 8600-8606.

[71] S. Ma, H. Lee, Y. Liang, F. Zhou, Angew. Chem. Int. Ed. 55 (2016) 5793-5797.

[72] H. Watanabe, A. Fujimoto, J. Nishida, T. Ohishi, A. Takahara, Langmuir 32 (2016)

4619-4623.

[73] M.J. Roman, E.A. Decker, J.M. Goddard, Colloids Interface Sci. Commun. 13 (2016) 10-13.

[74] Y. Guan, L. Shao, D. Dong, F. Wang, Y. Zhang, Y. Wang, RSC Adv. 6 (2016) 6996669972.

[75] S. Kim, D.S. Kim, S.M. Kang, Chem-Asian J. 9 (2014) 63-66.

[76] L. Yang, L. Han, J. Ren, H. Wei, L. Jia, Colloids Surf., A: Physicochem. Eng. Aspects 484 (2015) 197-205.

[77] C. Ringwald, V. Ball, J. Colloid Interface Sci. 450 (2015) 119-126.

[78] H. Ejima, J.J. Richardson, F. Caruso, Polym. J. 46 (2014) 452-459.

[79] J. Guo, H. Sun, K. Alt, B.L. Tardy, J.J. Richardson, T. Suma, H. Ejima, J. Cui, C.E.

Hagemeyer, F. Caruso, Adv. Healthc. Mater. 4 (2015) 1796-1801.

[80] T.J. Merkel, S.W. Jones, K.P. Herlihy, F.R. Kersey, A.R. Shields, M. Napier, J.C. Luft, H. Wu, W.C. Zamboni, A.Z. Wang, J.E. Bear, J.M. DeSimone, Proc. Natl. Acad. Sci. U. S.

A. 108 (2011) 586-591.

[81] S. Mettu, M. Zhou, B.L. Tardy, M. Ashokkumar, R.R. Dagastine, Polymer (2016) DOI:

10.1016/j.polymer.2016.1002.1046.

[82] E. Reissner, J. Math. Phys. 25 (1946) 80-85.

[83] E. Reissner, J. Math. Phys. 25 (1946) 279-300.

[84] Y. Bian, A. Masuda, T. Matsuura, M. Ito, K. Okushin, A.G. Engel, K. Ohno, Hum. Mol. Genet. 18 (2009) 1229-1237.

[85] A.O. Henriques, C.P. Moran Jr., Annu. Rev. Microbiol. 61 (2007) 555-588.

[86] D. Hong, M. Park, S.H. Yang, J. Lee, Y.G. Kim, I.S. Choi, Trends Biotechnol. 31 (2013) 442-447.

[87] S.H. Yang, D. Hong, J. Lee, E.H. Ko, I.S. Choi, Small 9 (2013) 178-186.

[88] J.H. Park, D. Hong, J. Lee, I.S. Choi, Acc. Chem. Res. 49 (2016) 792-800.

[89] Z. Hong, P. Mann, K.J. Shaw, B. Didomenico, Yeast 10 (1994) 1083-1092.

[90] J. Lee, J. Choi, J.H. Park, M.H. Kim, D. Hong, H. Cho, S.H. Yang, I.S. Choi, Angew.

Chem. Int. Ed. 53 (2014) 8056-8059. 
[91] T. Sylla, L. Pouységu, G. Da Costa, D. Deffieux, J.P. Monti, S. Quideau, Angew. Chem. Int. Ed. 127 (2015) 8335-8339.

[92] K. Zhan, H. Ejima, N. Yoshie, ACS Sustainable Chem. Eng. 4 (2016) 3857-3863.

[93] C.M. Spencer, Y. Cai, R. Martin, S.H. Gaffney, P.N. Goulding, D. Magnolato, T.H.

Lilley, E. Haslam, Phytochemistry 27 (1988) 2397-2409. 